\title{
Transcriptional profiles underlying parent-of-origin effects in seeds of Arabidopsis thaliana
}

\author{
Sushma Tiwari', Melissa Spielman', Reiner Schulz², Rebecca J Oakey², Gavin Kelsey³, Andres Salazar4 ${ }^{4}$ Ke Zhang ${ }^{4}$, \\ Roger Pennell ${ }^{4}$ and Rod J Scott*1
}

\begin{abstract}
Background: Crossing plants of the same species but different ploidies can have dramatic effects on seed growth, but little is known about the alterations to transcriptional programmes responsible for this. Parental genomic imbalance particularly affects proliferation of the endosperm, with an increased ratio of paternally to maternally contributed genomes ('paternal excess') associated with overproliferation, while maternal excess inhibits endosperm growth. One interpretation is that interploidy crosses disrupt the balance in the seed of active copies of parentally imprinted genes. This is supported by the observation that mutations in imprinted FIS-class genes of Arabidopsis thaliana share many features of the paternal excess phenotype. Here we investigated gene expression underlying parent-of-origin effects in Arabidopsis through transcriptional profiling of siliques generated by interploidy crosses and FIS-class mutants.
\end{abstract}

Results: We found that fertilized fis 1 mutant seeds have similar profiles to seeds with paternal excess, showing that the shared phenotypes are underpinned by similar patterns of gene expression. We identified genes strongly associated with enhanced or inhibited seed growth; this provided many candidates for further investigation including MADS-box transcription factors, cell cycle genes, and genes involved in hormone pathways.

Conclusions: The work presented here is a step towards understanding the effects on seed development of the related phenomena of parental genome balance and imprinting.

\section{Background}

Crossing plants of the same species but different ploidies often alters seed development, generating reciprocal phenotypes depending on the direction of the cross [1]. Particularly dramatic effects are seen in endosperm, a fertilization product derived from the diploid central cell and a haploid sperm that transfers nutrients from the seed parent to the developing or germinating embryo. In general, an increased ratio of paternally to maternally contributed genomes in the seed ('paternal excess')--generated for example by crossing a diploid seed parent with a tetraploid pollen parent--is associated with increased growth of endosperm, while an increased ratio of maternal to paternal genomes ('maternal excess') inhibits endosperm growth. A widely accepted interpretation of interploidy cross phenotypes is that they disrupt the balance in the seed of active copies of parentally imprinted

* Correspondence: bssrjs@bath.ac.uk

1 Department of Biology and Biochemistry, University of Bath, Claverton Down, Bath BA2 7AY, UK

Full list of author information is available at the end of the article genes, which, depending on the particular gene, are expressed from only the maternal or only the paternal alleles [1,2]. Study of imprinting in plants has focused on two model species, Arabidopsis thaliana and Zea mays; in both, parent-specific expression of imprinted genes is largely or exclusively confined to endosperm, with expression generally either biallelic or absent in the embryo [3-12]. To date, MATERNALLY EXPRESSED IN $E M B R Y O$ (MEE1) is the only known gene that is monoallelically expressed in the embryo [13].

In Arabidopsis, crosses between diploid and tetraploid plants often produce viable triploid embryos, with $2 \mathrm{xX} 4 \mathrm{x}$ crosses (diploid seed parent and tetraploid pollen parent) generating heavy seeds containing large embryos, and $4 \times X 2 x$ crosses producing light seeds with small embryos [14]. Paternal excess is associated with increased and prolonged proliferation of the endosperm, overgrowth of the chalazal endosperm and associated nodules, an abnormally large seed cavity, and delay in endosperm cellularization (normal endosperm development in Arabidopsis is described by Olsen, [15]), while maternal excess is 
characterized by inhibited endosperm division, small chalazal endosperm, absence of nodules, small seed cavity, and precocious cellularization and mitotic arrest of endosperm. Therefore the extent of endosperm growth is an important component in the final size of the seed and embryo even in a species with only one cell layer of endosperm remaining in the mature seed. Reciprocal crosses between diploid and hexaploid Arabidopsis plants produce more extreme versions of these phenotypes, and this level of parental genomic imbalance is also lethal: embryos arrest by heart stage, and the seeds abort. In maize, crosses between diploid and tetraploid plants usually result in seed abortion [16], but before this occurs, the developing seeds also display reciprocal phenotypes, with delayed endoreduplication (i.e. delayed differentiation) observed in kernels with paternal excess, and early mitotic arrest when there is maternal excess [17].

In Arabidopsis, a maternal mutation in any one of four 'FIS-class' genes--FERTILIZATION INDEPENDENT SEED 1 (FIS1)/MEDEA (MEA), FIS2, FIS3/FERTILIZATION INDEPENDENT ENDOSPERM (FIE), or MULTICOPY SUPPRESSOR OF IRA 1 (MSI1)--leads to seed abortion, with phenotypes including overexpansion of the seed cavity, failure of endosperm cellularization, large chalazal endosperm and nodules, and arrest of embryos around heart stage [18-22]. Intriguingly, these phenotypes are very similar to those resulting from interploidy crosses that generate a lethal level of paternal excess $[14,19,23]$. msi1 mutants deviate somewhat from this model in producing fewer peripheral endosperm nuclei than wild-type seeds, although chalazal endosperm and nodules are still enlarged [22]. FIS1/MEA was the first imprinted gene to be described in Arabidopsis. In endosperm, FIS1/MEA is expressed only from the maternally derived alleles, while it is biallelic in embryo, at least from torpedo stage onward [3,5]. FIS2 is expressed only from maternal alleles in developing seeds [11]. There is no molecular evidence for imprinting of the other FISclass genes. The four FIS-class gene products participate in Polycomb Repressive Complex (PRC) 2 [21,24,25], which, like animal PRCs inhibits transcription of target genes through epigenetic modification of chromatin $[26,27]$. The similarity of FIS-class mutant and lethal paternal excess phenotypes led to the proposal that one function of the wild-type FIS proteins is to repress transcription of loci in the maternally derived genome that are normally expressed only when paternally contributed [23]. This has been supported by the discovery that the FIS1/MEA-containing PRC2 represses the maternal alleles of PHERES1 (PHE1), an imprinted gene which is preferentially expressed from the paternal genome $[10,28]$.

Another feature of FIS-class mutants is an 'autonomous endosperm' phenotype. Wild-type Arabidopsis embryo sacs must be fertilized before the egg or central cell will divide. In contrast, if FIS-class mutant flowers are prevented from self-pollinating, the central cell nevertheless divides and forms a syncytial structure resembling peripheral endosperm, even though there is no cellularization or regional specification [19,21,29,30]. In msi1 mutants, the unfertilized egg also divides to form a small multicellular structure expressing several markers for embryogenesis [31]. The seed-like structures produced by unfertilized FIS-class mutant ovules invariably abort. Comparison of gene expression in fertilized and unfertilized FIS-class mutants could reveal genes that are normally repressed by PRC2 in seeds.

In the work presented below, we investigated gene expression underlying paternal and maternal excess phenotypes using two different microarray platforms, and also profiled fertilized and unfertilized FIS-class mutants. This project had several goals, including the identification of genes that are not necessarily imprinted, but which are nevertheless associated with promoting or inhibiting seed growth; and comparing gene expression between seeds from interploidy crosses and FIS-class mutants. Another goal was to gather molecular data to help us position fertilized and unfertilized FIS-class mutants on the maternal-paternal spectrum. We found that fertilized fis1 mutant seeds have similar transcriptional profiles to seeds with paternal excess, showing that the shared phenotypes are underpinned by similar patterns of gene expression. To learn more about regulation of seed size, we filtered our data for sets of genes strongly associated with enhanced or inhibited seed growth. Our results illustrate the molecular link between paternal excess and FIS-class mutations, and potentially provide tools for altering seed size.

\section{Results and Discussion}

\section{Generation of samples and hybridization to arrays}

To explore the patterns of gene expression underlying the phenotypes of seeds generated by interploidy crosses and FIS-class mutants, we performed two independent microarray experiments using biological replicate samples and different array platforms to increase confidence in the results. Other cross-platform comparisons have been successful in Arabidopsis [32].

For our first experiment, RNA was extracted from siliques at 5 DAP resulting from the crosses $6 \times \mathrm{XX} 2 \mathrm{x}$ and $4 \times X 2 x$ (maternal excess), 2xX2x (balanced), $2 x X 4 x$ and 2xX6x (paternal excess), and fis1/meaX2x, and hybridized to custom Agilent 22K two-dye (Cy3 and Cy5) arrays (http://www.chem.agilent.com; http://www.ceresinc.com). For the second experiment, RNA was extracted at 5 DAP from two further independent biological samples of the crosses listed above, and also from unfertilized siliques of male-sterile msi1 mutants at 7 days after floral 
opening (see Methods), and hybridized to Affymetrix ATH1 full-genome chips http://www.affymetrix.com. Thus, our experiments incorporated seeds from interploidy crosses generating both viable and lethal parental imbalance, a fertilized FIS-class mutant that develops with a phenotype resembling lethal paternal excess, and an unfertilized FIS-class mutant that develops with no paternal contribution.

The phenotypes of all crosses are illustrated in Figure 1. At 5 DAP, seeds with the normal balance of maternal to paternal genomes $(2 \times X 2 x$ cross, generating a $2 \mathrm{~m}: 1 \mathrm{p}$ endosperm) typically contain a heart-stage embryo, peripheral endosperm which has begun to cellularize from the micropylar pole, a compact chalazal endosperm, and endosperm nodules (Fig. 1C). In seeds with paternal excess $(2 \mathrm{xX} 4 \mathrm{x}$ and $2 \mathrm{xX} 6 \mathrm{x})$ there is no cellular endosperm at this stage, and the chalazal endosperm is enlarged (Fig. 1D, E). fis1X2x seeds (Fig. 1F) likewise contain only freenuclear endosperm, and in common with 2xX6x crosses, the endosperm never cellularizes and the seeds abort
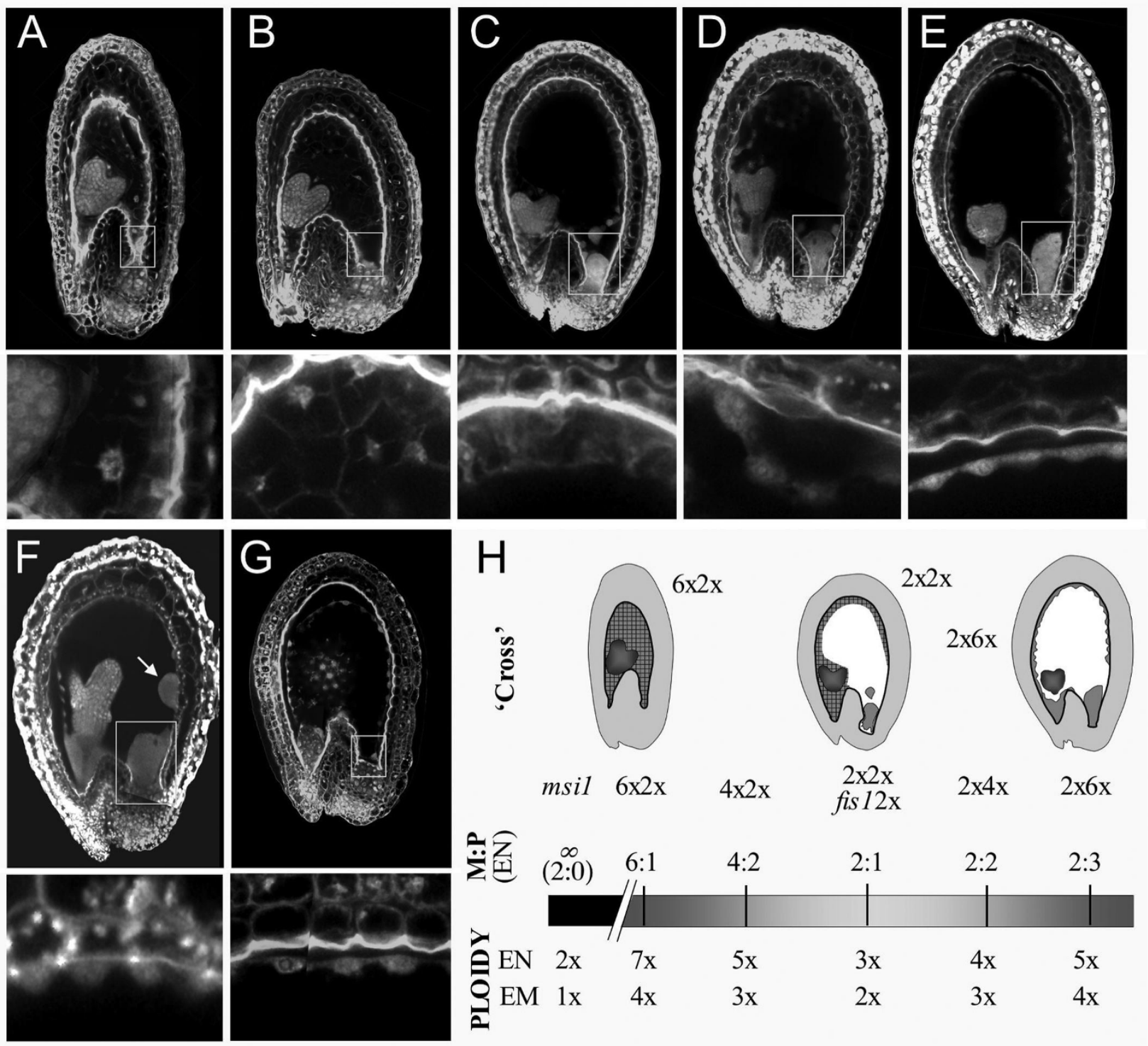

Figure 1 Phenotypes and genetic constitution of seeds used for transcriptional profiling. (A-G) Confocal micrographs of seeds at 5 days after pollination (7 days after flowering for msi 7 ). Boxes surround the chalazal region. Below each composite seed image is an enlargement showing peripheral endosperm. Seed genotypes are: (A) 6xX2x, (B) 4xX2x, (C) 2xX2x, (D) 2xX4x, (E) 2xX6x, (F) fis 1X2x, (G) msi1 (autonomous seed produced by an unfertilized msilmutant ovule). Arrow in (F) indicates endosperm nodules. (H) Spectrum of maternal:paternal genomic balance. Above bar: ratio of maternally to paternally derived genomes in the endosperm for each 'cross' (sexual crosses + unfertilized msi 7 ). Below bar: absolute number of genomes in endosperm (EN) and embryo (EM) for each 'cross'. 
$[14,18,33]$. Fertilized fis1 mutants also produce greatly enlarged endosperm nodules. Therefore the characteristic phenotypes both of paternal excess and of a fertilized FIS-class mutant include overproliferation of endosperm and delay or failure of cellularization. At the other end of the phenotypic spectrum, seeds with maternal excess $(4 \mathrm{xX} 2 \mathrm{x}$ and $6 \mathrm{x} \mathrm{X} 2 \mathrm{x})$ produce small endosperms that cellularize precociously, and tiny chalazal endosperms with no associated nodules (Fig. 1B, A). The endosperm fails to cellularize in unfertilized msi1 mutants (Fig. 1G) but these also lack chalazal endosperm, so are difficult to classify according to endosperm growth and morphology.

Figure $1 \mathrm{H}$ illustrates the absolute numbers of genomes in embryo and endosperm for each seed genotype, and places each seed on a spectrum of maternal:paternal genomic balance in the endosperm. Although fis $1 \mathrm{X} 2 \mathrm{x}$ seeds contain the same number of genomes and the same genomic balance as $2 \mathrm{xX} 2 \mathrm{x}$, both phenotypic (endosperm overproliferation) and molecular evidence (ectopic expression of the normally repressed maternal allele of PHE1) indicates that they may be regarded as having 'virtual' paternal excess $[10,23]$. Unfertilized msilmutants contain no paternal genomes, but may also share some features of paternalization due to the mutation.

RNA hybridization and statistical analysis for each microarray platform are described in the Methods. Results for the Affymetrix and Agilent experiments are available through GEO http://www.ncbi.nlm.nih.gov/geo under the accession number GSE20007. Correspondence between Affymetrix and Agilent probes was determined as described in the Methods. This yielded a list of 20,442 genes that we used in the subsequent analysis (cf. 33,518 Arabidopsis genes annotated in TAIR Release 9.0 (http:// www.arabidopsis.org, [34]). We subtracted from this list all genes that were below a threshold of absolute expression in all samples, or which had widely differing ratios in the dye-swap experiments indicating unreliable expression (see Methods), giving a final list of 14,944 unique AtIds that were called present in at least one sample. These AtIds, along with the corresponding Agilent and Affymetrix probesets and averaged SLR and PSLR values (see Methods), are provided in Additional file 1 table S1 online. Interestingly 1,947 of the 2,608 genes predicted to be early seed specific by Day et al [35], were found to be present in our dataset (Additional file 1 table S1.1.). Of the genes called present in the peripheral endosperm of the Goldberg and Harada dataset http://seedgenenetwork.net/arabidopsis a similar proportion (74\%) were also represented in our dataset (data not shown). This gives us the confidence that using whole siliques as the experimental material captures a significant proportion of the endosperm expressed genes.

\section{Differential transcript accumulation reflects altered developmental programmes, not increased gene dosage}

To identify genes that were over- or underexpressed ('up' or 'down') in each interploidy cross or FIS-class mutant relative to $2 \mathrm{xX} 2 \mathrm{x}$, we generated lists of genes with signal$\log$ ratios (SLRs) $\geq 0.6$ or $\leq-0.6$, corresponding to changes in expression of approximately $50 \%$ up or down; many genes had much higher changes than this. For Affymetrix data we based the lists on p-value weighted SLRs (pSLR) to minimize interference from values for which there was little statistical evidence for differential expression (see Methods and [36]). Genes called up or down together with their SLRs/pSLRs are presented in Additional file 2 table S2 online. We next compared over- and underexpressed genes across platforms for each cross; for example we ultimately only called a gene up if its SLR was $\geq 0.6$ in both Affymetrix and Agilent datasets. The lists of genes called up and down that were supported by both platforms are provided in Additional file 3 table S3 online.

Table 1 shows the numbers of genes called up or down in each sample and platform, along with genes in common across platforms. $2 \mathrm{xX} 4 \mathrm{x}$ crosses showed the least amount of misexpression, and $6 \times \mathrm{XX} 2 \mathrm{x}$ the greatest. In fis $1 \mathrm{X} 2 \mathrm{x}$ seeds, which differ from wild-type by a premature stop codon in a single ORF [18], 401 genes were called up in both platforms, while in phenotypically similar 2xX6x crosses, which have triple the normal number of paternal genomes in the seed, only 288 genes were called up. This suggests that interploidy crosses provide less disturbance to gene expression than FIS-class mutations and can be a valid route to exploring imprinting. We also observed that in the interploidy crosses there was no general bias towards overexpression of genes, though the seeds all contained more genomes than $2 \times X 2$ x seeds (Fig. 1). This rules out a simple relationship between gene dosage and level of gene expression, instead indicating that differential gene expression observed here in many cases represents genuine changes to developmental programmes.

The extent of agreement between the Affymetrix and Agilent datasets was calculated as the percentage of genes in common out of the possible maximum (Table 1). The overlap between datasets ranged between 24.6 and 55.9\%; this compares favourably with the results of Pylatuik and Fobert [32], who recorded cross-platform overlaps of 14.3 to $25.5 \%$ between sets of Arabidopsis genes overexpressed 2.5-fold.

We next investigated whether the sets of genes called up in the two crosses generating paternal excess had more in common with each other than with genes up in maternal excess, and vice versa. The results of these comparisons are represented in Figure 2. We found that data- 
Table 1: Cross-platform comparison of genes called up and down.

\begin{tabular}{|c|c|c|c|c|c|}
\hline Cross & Affymetrix & Agilent & overlap & $\%$ agreement & $\%$ transcription factors \\
\hline $2 \times \times 4 \times$ up & 597 & 755 & 157 & 26.3 & 12.1 \\
\hline $2 \times \times 4 \times$ down & 818 & 378 & 93 & 24.6 & 14 \\
\hline $2 \times \times 6 \times$ up & 821 & 814 & 288 & 35.4 & 10.8 \\
\hline $2 \times \times 6 \times$ down & 877 & 1072 & 392 & 44.7 & 13.6 \\
\hline $4 \times \times 2 \times$ up & 1164 & 870 & 300 & 34.5 & 7.3 \\
\hline $4 \times \times 2 \times$ down & 1854 & 801 & 326 & 40.7 & 8.6 \\
\hline $6 \times \times 2 \times$ up & 1388 & 2109 & 776 & 55.9 & 9.7 \\
\hline $6 \times \times 2 \times$ down & 1859 & 2333 & 921 & 49.5 & 7.5 \\
\hline fis $1 \times 2 \times$ up & 1068 & 2582 & 401 & 37.5 & 10.5 \\
\hline fis $1 \times 2 \times$ down & 1904 & 3039 & 710 & 37.3 & 11.3 \\
\hline msi1 up & 1691 & & & & 10.2 \\
\hline msi1 down & 2414 & & & & 7.6 \\
\hline
\end{tabular}

The numbers of genes called up or down for each cross and each platform are shown, along with the numbers of genes in common across both platforms for each cross ('overlap'), and the percentage of the maximum possible agreement between platforms. The right-hand column shows the percentage of each list consisting of transcription factors (http://datf.cbi.pku.edu.cn; Guo et al., 2005). For all samples except for $m s i 1$ the percentage of transcription factors was calculated from the lists of genes called up or down in both platforms ('overlap'). See Additional file 2 table $\mathrm{S} 2$ for genes called up or down in each platform and Additional file 3 table $\mathrm{S} 3$ for genes called up or down in both platforms.

sets from phenotypically similar crosses had a higher proportion of genes in common than datasets from opposite crosses. For example, the correspondence between genes called up in 2xX4x and 2xX6x was $46 \%$ of the possible maximum (the number of genes in the smaller set, in this case $2 \times X 4 x$ up), although one of these crosses produces viable seeds and the other is lethal; while the overlap between genes up in $2 \times \mathrm{X} 4 \mathrm{x}$ and $4 \mathrm{x} \mathrm{X} 2 \mathrm{x}$ seeds, which are both viable, was only $10 \%$ of the maximum. These results also indicate that overexpression observed in these experiments is much more likely to reflect genuine changes in developmental programmes than simply the presence of extra copies of genes in seeds with increased ploidy. We next compared genes called up in fis1X2x with those up in the two lethal interploidy crosses. More than $50 \%$ of genes overexpressed in $2 \times X 6 x$ were also up in fis $1 \mathrm{X} 2 \mathrm{x}$, while only $7 \%$ of genes up in $6 \mathrm{xX} 2 \mathrm{x}$ were up in fis $1 \mathrm{X} 2 \mathrm{x}$, supporting the hypothesis that FIS-class mutations have a paternalizing effect on seed development.

We assayed gene expression at a relatively early stage since we are especially interested in identifying genes that control seed development. Nevertheless, we expected that some genes would be over- or underexpressed as a consequence of altered development rather than as a cause. To assess whether genes showing differential expression at 5 DAP could be regulators of seed development, we compared the list of 1922 transcription factors annotated in the Arabidopsis genome (http:// datf.cbi.pku.edu.cn; [37]) with the sets of genes we called up or down. There are 27,379 protein coding genes anno- tated in TAIR release 9.0 http://www.arabidopsis.org. So, approximately $7.0 \%$ of the genome consists of transcription factors. A similar proportion, $8 \%(1,192)$, of the genes called present in our experiment are on the transcription factor list. However most of our up or down lists contained a higher proportion than this (Table 1). We conclude that genes controlling seed development, rather than merely responding to upstream changes, are well represented in our transcription profiles.

\section{Validation of microarray data}

To validate the microarray data we examined the expression of 20 genes using quantitative real-time PCR (qRT$\mathrm{PCR})$. These genes were mainly chosen because of their expression trends in the microarray data, and some will be discussed in more detail below. Results are presented in Additional file 4 table S4 online and summarized in Table 2, which shows the extent of agreement between each microarray platform and qRT-PCR for the 20 genes. Out of 220 calls tested (11 calls for each of 20 genes), microarray and qRT-PCR data gave the same call for 170 (i.e. for a particular cross and platform, a gene was called up, down, or unchanged in both the microarray and the qRT-PCR experiments), giving overall agreement of $77 \%$. A similar level of agreement between microarray and qRT-PCR data for transcription in maize anthers was recently reported by Skibbe et al. [38]. Where our microarray and qRT-PCR calls did not agree, the majority nevertheless had fold changes in the same direction (Additional file 4 table S4). Only one sample, 4xX2x Agi- 
A
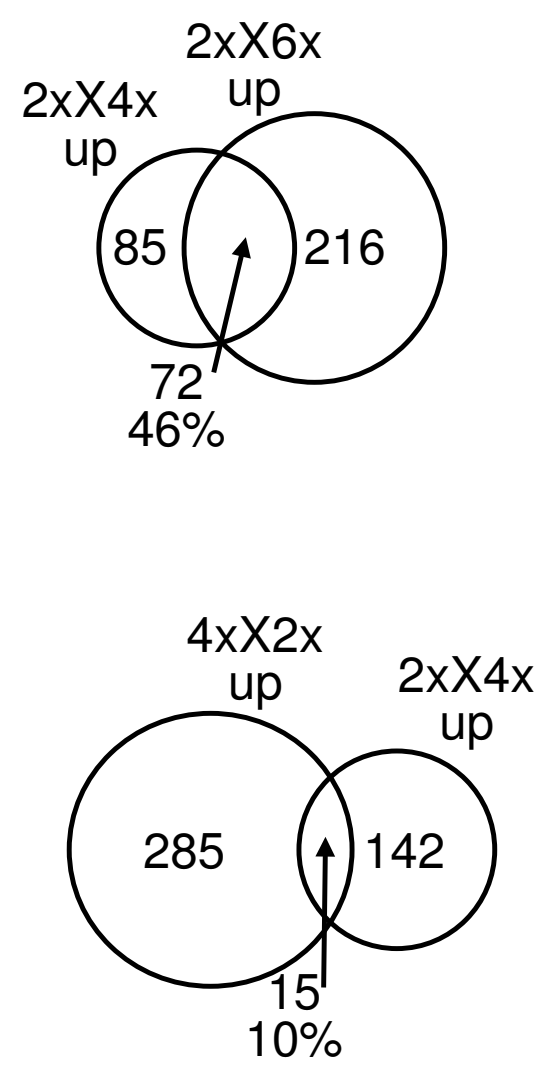

B

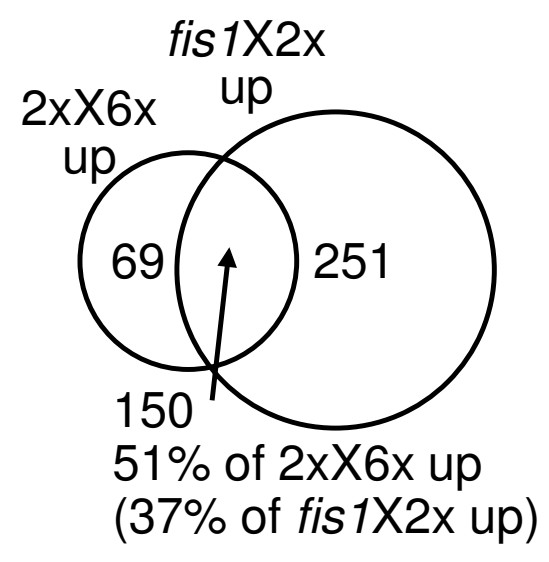

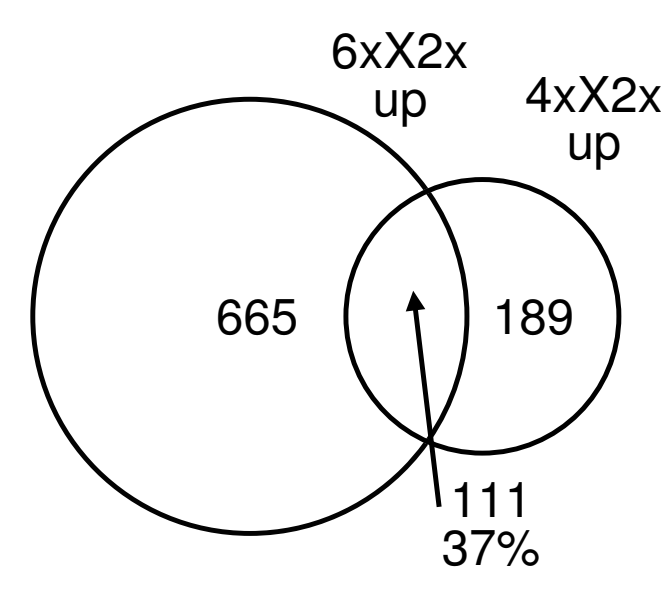
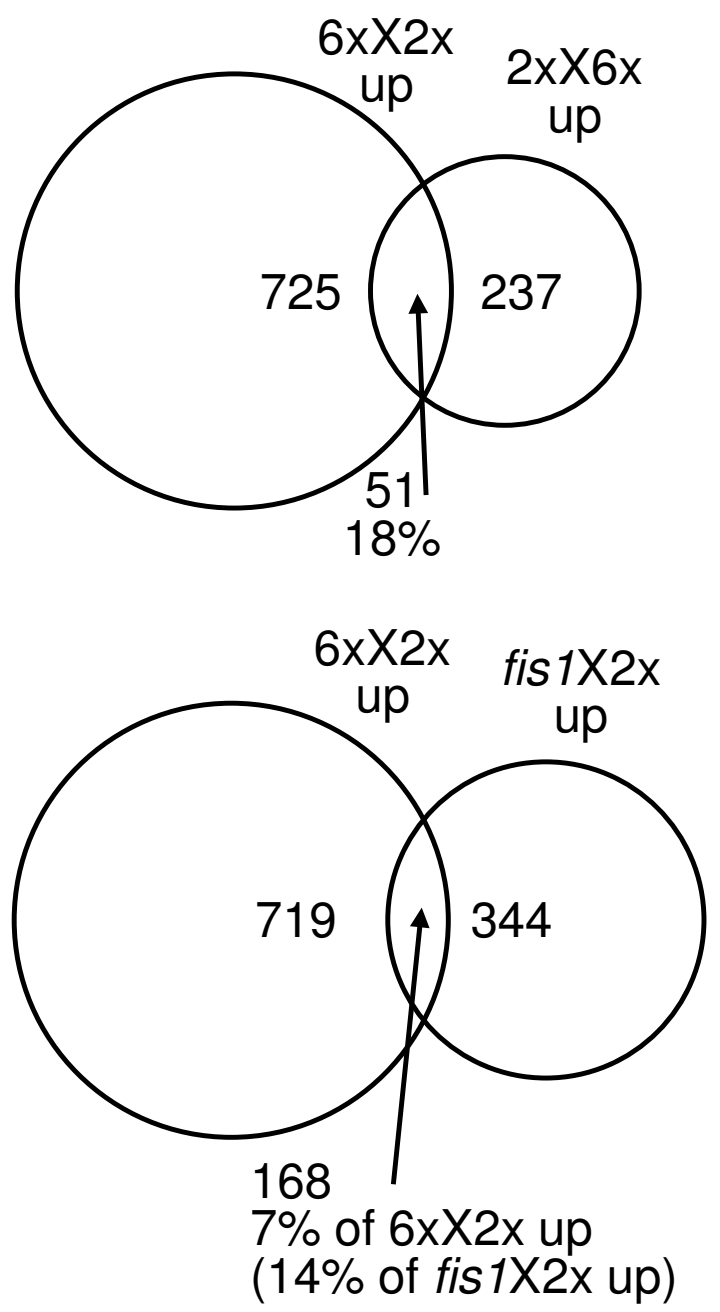

Figure 2 Extent of agreement between sets of genes called up. The percentage shown in the region of overlap is the percentage of the maximum possible agreement for each pair. (A) Agreement between interploidy crosses generating paternal and maternal excess. (B) Agreement between fis $1 \times 2 x$ and the two extreme interploidy crosses. 
Table 2: Agreement of microarray and qRT-PCR data.

\begin{tabular}{lllllll}
\hline & msi1 & $\mathbf{6 x X 2 x}$ & $\mathbf{4 x X 2 x}$ & $\mathbf{2 x X 4 x}$ & 2xX6x & fis1X2x \\
\hline Affymetrix & $13(65 \%)$ & $15(75 \%)$ & $18(90 \%)$ & $14(70 \%)$ & $17(85 \%)$ & $18(90 \%)$ \\
Agilent & & $15(75 \%)$ & $8(40 \%)$ & $17(85 \%)$ & $19(95 \%)$ & $16(80 \%)$ \\
\hline
\end{tabular}

Expression of 20 genes was tested using qRT-PCR and calls of up, down, or not changed were compared with calls for the same genes in the microarray data. Each cell shows the number (percentage) of calls that agreed out of a maximum of 20. qRT-PCR results are provided in Additional file 4 table $S 4$.

lent, had less than $65 \%$ agreement with the qRT-PCR findings. None of the genes from this dataset where qRTPCR and the Agilent data disagreed were called changed in both Agilent and Affymetrix platforms, and therefore were not included in our final list of genes called down in this cross. We conclude from our validation that the microarray data is particularly robust for genes that show the same expression trend in both platforms.

\section{Hierarchical clustering of expression data identifies maternal and paternal groups}

We were interested in testing whether the crosses generating paternal or maternal excess had similar expression patterns, and we also wanted to position the fertilized and unfertilized FIS-class mutants on the maternalpaternal spectrum. We used hierarchical clustering [39] to compare expression trends among all samples. Repeated clustering using different distance measures (see Methods) robustly showed distinct 'paternalized' and 'maternalized' transcriptome sets, where $2 \mathrm{xX} 4 \mathrm{x}, 2 \mathrm{xX} 6 \mathrm{x}$, and fis $1 \mathrm{X} 2 \mathrm{x}$ formed the paternalized cluster and $4 \mathrm{xX} 2 \mathrm{x}$, $6 \mathrm{xX} 2 \mathrm{x}$, and parthenogenetic $m s i 1$ belonged to the maternalized cluster (Fig. 3). Principal Components Analysis of the microarrays also gave results which are consistent with the hierarchical clustering (not shown).

The transcriptional profile of fis $1 \mathrm{X} 2 \mathrm{x}$ crosses is most similar to the profiles of $2 \times \mathrm{X} 6 \mathrm{x}$ seeds from both platforms. This supports a model in which FIS-class mutations 'paternalize' the maternally inherited genomes in the endosperm by removing crucial maternal-specific function, so that the balance of maternal:paternal genomes is in effect more like the ratio generated by $2 \mathrm{xX} 6 \mathrm{x}$ crosses [23]. Although msi1 is also a FIS-class mutant, it was not pollinated for our experiment, and therefore not surprisingly had a very different transcriptional profile from fertilized fis1 seeds. msi1 clustered most closely with $6 \times \mathrm{XX} 2 \mathrm{x}$; this may reflect shared features such as near or total absence of chalazal endosperm.

\section{Association of gene ontologies with different seed phenotypes}

To determine whether categories of genes with particular biological function were associated with different seed phenotypes, we looked for GO (gene ontology) biological process terms [40] that were over- or underrepresented among genes showing differential expression, using the GOstat tool available at http://gostat.wehi.edu.au[41]. We compared the list of 14,944 genes called present in the experiment (Additional file 1 table S1) with genes that were called up or down in the interploidy crosses and in fis $1 \mathrm{X} 2 \mathrm{x}$.

Selected Biological process terms that occurred with significantly enhanced or reduced frequency $(\mathrm{P}<0.05$, adjusted using the Benjamini and Hochberg correction for multiple testing) are shown in Table 3. Some terms were omitted because of redundancy. Not all up and down lists contained categories with altered frequency. Loci called down in 2xX6x and fis1X2x were enriched for genes involved in cell cycle regulation. Downregulated genes in triploid seeds have previously been found to be enriched in genes within the functional category of cell cycle regulation [42]. This was at first surprising given the overproliferation of 2xX6x and fis1X2x endosperms, but these seeds also display aberrations in the cell cycle such as failure of endosperm cellularization. Strikingly, 44 of the genes called down in 2xX6x and 22 of the genes called down in fis1X2x are among a set of 82 Arabidopsis genes recently identified as showing an expression peak at the G2/M boundary in synchronized cell culture [43]. Mitosis-specific genes called down in 2xX6x and/or fis1X2x include the syntaxin SYP111/KNOLLE (At1g08560); several kinesins such as HINKEL/ATNACK1 (At1g18370) and ZCF125 (At1g59540); the mitotic cyclins CYCB1;4 (At2g26760), CYCB1;3 (At3g11520), and CYCB1;2 (At5g06150); CDKB2;1 (At1g76540), a cyclin-dependent kinase involved in the G2/M transition; and the myb family transcription factor MYB3R-4 (At5g11510). SYP111/ KNOLLE is expressed in mitotically dividing cells and in cellularizing endosperm, and is required for membrane vesicle fusion in the plane of cell division [44]. Kinesins associate with microtubules and are involved in cytoskeleton organization and transport of vesicles and organelles; HIK/ATNACK1 is essential for cell plate formation during mitotic cytokinesis [45] and ZCF125 is involved in interactions between the spindle and the kinetochores of chromosomes [46]. MYB3R-4 is proposed to regulate genes involved in the G2/M transition [43]. Nearly $80 \%$ of 
the mitosis-specific genes downregulated in $2 \mathrm{xX} 6 \mathrm{x}$ are also called down in $6 \times \mathrm{X} 2 \mathrm{x}$, perhaps because cell division has ceased in seeds with lethal maternal excess by this stage. Underexpression of genes involved in DNA replication initiation in $6 \times \mathrm{X} 2 \mathrm{x}$, is consistent with reduced division in $6 \mathrm{xX} 2 \mathrm{x}$.

\section{Association of individual gene expression with seed phenotypes}

To learn more about factors involved in controlling seed size, we were interested in identifying the genes most strongly associated with enhanced or inhibited seed growth. To determine the genes with the most robust associations we used several filtering criteria. (1) As described above, we only called a gene up or down in interploidy crosses if this was supported in both platforms. (2) We next looked for intersections of gene sets that were up or down in crosses generating phenotypically similar seeds. For example, to find the genes strongly associated with enhanced endosperm/seed growth we chose genes overexpressed in both $2 \mathrm{xX} 4 \mathrm{x}$ and $2 \mathrm{xX} 6 \mathrm{x}$ crosses. (3) After identifying genes called up in seeds in one phenotypic class, we applied a further condition that those genes should not be up in the opposite class. This was to avoid false positives from genes that may have been overexpressed because of polyploidy, stress, or other causes affecting seeds irrespective of the extent of their growth. To increase the selectivity of the final lists we used broad definitions for 'not up' and 'not down': we called a gene 'not up' if the Agilent SLR and Affymetrix pSLR were both equal to or below 0.3 (corresponding to a change in expression of approximately $20 \%$ ), and 'not down' if the SLRs/pSLRs were $=-0.3$. For example, our list of genes strongly associated with endosperm overproliferation were called 'up' in 2xX4x and 2xX6x, and also 'not up' in $4 x X 2 x$ and $6 x \times 2 x$.
The lists of seed class-associated genes, along with annotations and GO biological process terms (http:// www.arabidopsis.org; [40]), are presented in Additional file 5 table 5 online. The first group (Additional file 5 table S5, S5.1-3) comprises lists of 'large seed genes' (we have used 'large seeds' as a shorthand for seeds with increased endosperm proliferation, even though in lethal crosses these seeds are only large while they are still alive). These genes are positively associated with large seeds (up in combinations of 2xX4x, 2xX6x, and fis $1 \mathrm{X} 2 \mathrm{x}$, not up in $4 \times \mathrm{x} 2 \mathrm{x}$ and $6 \mathrm{xX} 2 \mathrm{x}$ ), or negatively associated with small seeds (down in combinations of $4 x X 2 x, 6 x X 2 x$, and $m s i 1$, and not down in $2 \mathrm{xX} 4 \mathrm{x}$ and $2 \mathrm{xX} 6 \mathrm{x}$ ). We considered genes up in $2 \mathrm{x} \times 4 \mathrm{x}$ and $2 \mathrm{x} \times 6 \mathrm{x}$ and not up in $4 \mathrm{xX} 2 \mathrm{x}$ and $6 \mathrm{xX} 2 \mathrm{x}$ to be particularly strongly associated with promoting or responding to seed growth; these are shown in Table 4. The second group (Additional file 5 table S5, S5.4-6) contains lists of 'small seed genes', which are positively associated with small seeds (up in combinations of $4 \times \mathrm{X} 2 \mathrm{x}, 6 \mathrm{xX} 2 \mathrm{x}$, and $m$ sil, and not up in $2 \mathrm{xX} 4 \mathrm{x}$ and $2 \times \mathrm{x} 6 \mathrm{x})$ or negatively associated with large seeds (down in $2 \mathrm{xX} 4 \mathrm{x}$ or in $2 \mathrm{xX} 6 \mathrm{x}$ and fis $1 \mathrm{X} 2 \mathrm{x}$, not down in $4 x X 2 x$ and $6 x X 2 x)$. Genes up in $4 x X 2 x$ and $6 x \times 2 x$ and not up in 2xX4x and 2xX6x are shown in Table 6. We also constructed a list of genes called up in the two FIS-class mutants (Additional file 5 table S5, S5.7) (up in fis1X2x and $m s i 1$ ), to identify genes overexpressed in both fertilized and unfertilized seeds with impaired function of the PRC2 that contains FIS1/MEA and MSI1.

\section{Genes associated with large/overproliferating seeds}

There were 114 genes called up in $2 \mathrm{xX} 4 \mathrm{x}$ but not up in crosses generating maternal excess (Additional file 5 table S5, S5.1). More than half (62) were also up in $2 \times X 6 x$ (Table 4), and all but ten of these were likewise overexpressed in fis1X2x. This underlines the similarities in transcription profiles not only between interploidy crosses generating different degrees of paternal excess,

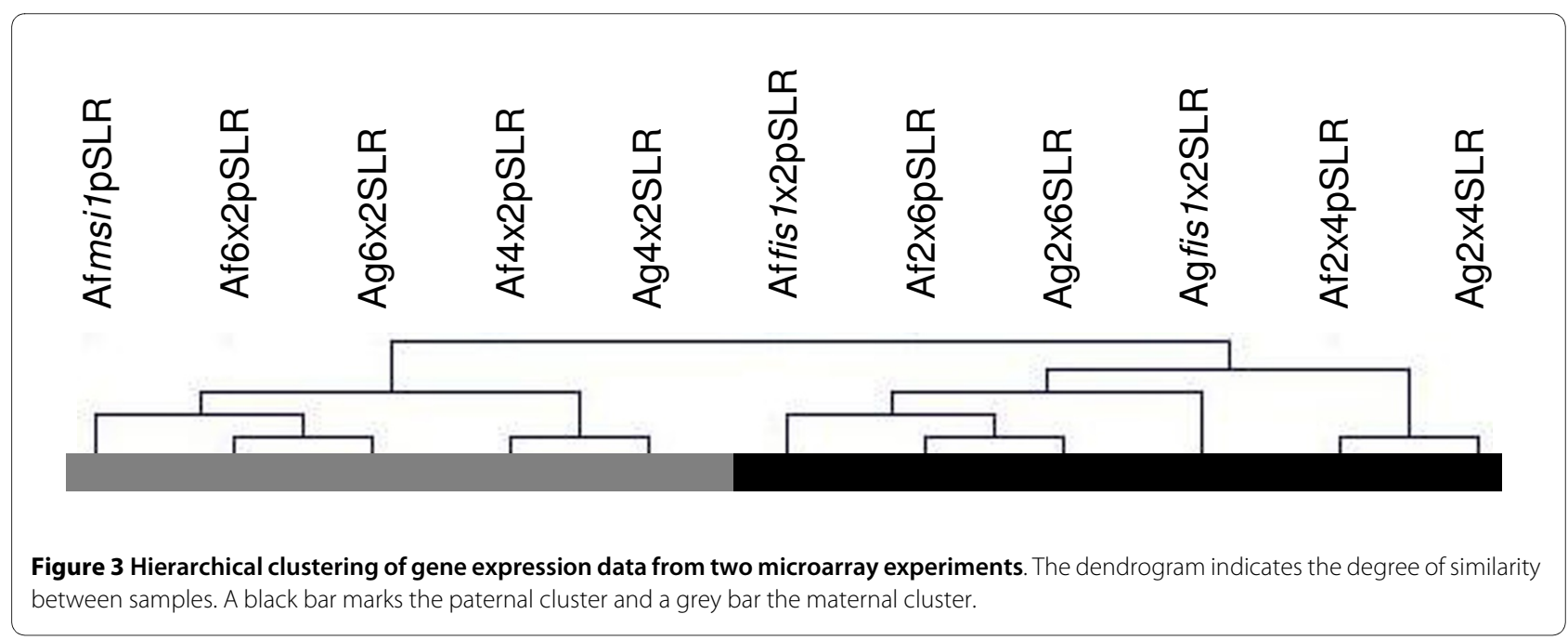


Table 3: Selected GO biological process terms over- and underrepresented among genes called up and down.

\begin{tabular}{|c|c|c|c|c|}
\hline sample & GO term & no. (\%) in sample & no. (\%) in all genes & $\begin{array}{l}\text { P-value } \\
\text { bold = underrepresented }\end{array}$ \\
\hline \multicolumn{5}{|c|}{$\begin{array}{l}\text { all genes in experiment } \\
n=11,091 \text { annotated }\end{array}$} \\
\hline \multirow{2}{*}{$\begin{array}{l}2 \times X 4 \times \text { down } \\
n=71 \text { annotated }\end{array}$} & response to stimulus & $15(21.12)$ & $817(7.3)$ & 0.00159 \\
\hline & $\begin{array}{l}\text { regulation of transcription, } \\
\text { DNA-dependent }\end{array}$ & $8(11.26)$ & $374(3.37)$ & 0.0181 \\
\hline \multirow[t]{2}{*}{$\begin{array}{l}2 \times X 6 x \text { up } \\
n=228 \text { annotated }\end{array}$} & $\begin{array}{l}\text { cell wall organization and } \\
\text { biogenesis }\end{array}$ & $8(3.5)$ & $80(0.72)$ & 0.0371 \\
\hline & inorganic anion transport & $4(1.75)$ & $20(0.18)$ & 0.0483 \\
\hline \multirow[t]{3}{*}{$\begin{array}{l}2 x X 6 x \text { down } \\
n=302 \text { annotated }\end{array}$} & $\begin{array}{l}\text { microtubule-based } \\
\text { movement }\end{array}$ & $9(2.98)$ & $26(0.23)$ & $2.56 \mathrm{e}-06$ \\
\hline & regulation of cell cycle & $7(2.31)$ & $38(0.34)$ & 0.00426 \\
\hline & steroid metabolic process & $4(1.32)$ & $18(0.16)$ & 0.0373 \\
\hline $\begin{array}{l}\text { fis } 1 \times 2 \times \text { up } \\
n=304 \text { annotated }\end{array}$ & $\begin{array}{l}\text { carbohydrate metabolic } \\
\text { process }\end{array}$ & $27(8.88)$ & $351(3.16)$ & 7.88 e-06 \\
\hline \multirow{6}{*}{$\begin{array}{l}\text { fis } 1 \times 2 \times \text { down } \\
n=541 \text { annotated }\end{array}$} & biosynthetic process & $16(2.77)$ & $773(6.96)$ & 0.0342 \\
\hline & electron transport & $33(6.09)$ & $352(3.17)$ & 0.0295 \\
\hline & $\begin{array}{l}\text { regulation of biological } \\
\text { process }\end{array}$ & $63(11.64)$ & $838(7.55)$ & 0.0342 \\
\hline & regulation of cell cycle & $8(1.47)$ & $38(0.34)$ & 0.0345 \\
\hline & sequestering of lipid & $4(0.73)$ & $8(0.72)$ & 0.0342 \\
\hline & $\begin{array}{l}\text { response to chemical } \\
\text { stimulus }\end{array}$ & $31(5.73)$ & $348(3.13)$ & 0.0399 \\
\hline $\begin{array}{l}4 \times \times 2 \times \text { up } \\
n=219 \text { annotated }\end{array}$ & cellular process & $44(20.09)$ & $3665(33.0)$ & 0.0141 \\
\hline \multirow{4}{*}{$\begin{array}{l}6 \times \times 2 \times \text { up } \\
n=554 \text { annotated }\end{array}$} & defense response & $30(5.41)$ & 189(1.70) & 8.11 e-09 \\
\hline & response to stimulus & $67(12.09)$ & $817(7.36)$ & 0.00345 \\
\hline & response to starvation & $5(0.9)$ & $14(0.13)$ & 0.019 \\
\hline & $\begin{array}{l}\text { macromolecule metabolic } \\
\text { process }\end{array}$ & $73(13.17)$ & $2300(20.74)$ & 0.00246 \\
\hline \multirow{4}{*}{$\begin{array}{l}6 \times X 2 \times \text { down } \\
n=697 \text { annotated }\end{array}$} & translation & $41(5.88)$ & $276(2.49)$ & 2,76 e-06 \\
\hline & $\begin{array}{l}\text { macromolecule } \\
\text { biosynthetic process }\end{array}$ & $48(6.88)$ & $380(3.42)$ & 5.57 e- 05 \\
\hline & $\begin{array}{l}\text { macromolecule metabolic } \\
\text { process }\end{array}$ & $185(26.54)$ & $2300(20.73)$ & 0.00551 \\
\hline & DNA replication initiation & $4(0.57)$ & $7(0.06)$ & 0.0207 \\
\hline
\end{tabular}


Table 3: Selected GO biological process terms over- and underrepresented among genes called up and down. (Continued)

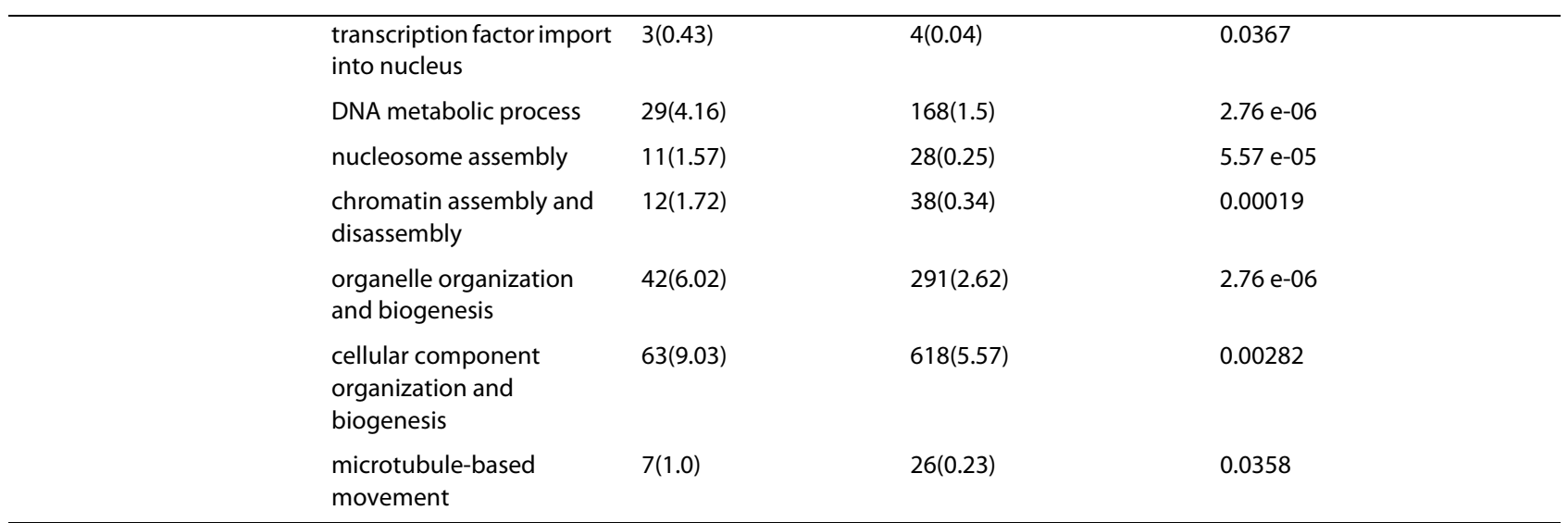

The GOstat tool (http://gostat.wehi.edu.au/; Beissbarth and Speed, 2004) was used to identify GO biological process terms significantly (P<0.05) over- and underrepresented among genes called up and down. P-values were adjusted using the Benjamini and Hochberg correction for multiple testing. Each list was compared with the set of all genes called present in the experiment.

$\mathrm{n}=$ number of genes in each list with $\mathrm{GO}$ biological process annotation.

but between these and fis1 mutant seeds. Ninety-five genes were up in $2 \times \mathrm{xX} 6 \mathrm{x}$ and fis $1 \mathrm{X} 2 \mathrm{x}$ but not $4 \mathrm{xX} 2 \mathrm{x}$ and $6 x X 2 x$ (Additional file 5 table S5, S5.2), of which 43 were not also up in $2 \mathrm{xX} 4 \mathrm{x}$, and therefore associated with an extreme paternal excess phenotype. Finally there were 158 genes called down in $4 \times \mathrm{X} 2 \mathrm{x}$ but not down in $2 \mathrm{xX} 4 \mathrm{x}$ and 2xX6x (Additional file 5 table S5, S5.3), including 52 also down in $6 \times \mathrm{x} 2 \mathrm{x}$, and 32 down in $4 \times \mathrm{x} 2 \mathrm{x}, 6 \mathrm{xX} 2 \mathrm{x}$, and msi1. Twelve genes were up in $2 \mathrm{xX} 4 \mathrm{x}, 2 \mathrm{xX} 6 \mathrm{x}$, and fis $1 \mathrm{X} 2 \mathrm{x}$ and also down in 4xX2x and 6xX2x (Table 4), indicating especially strong positive association with seed growth.

Transcription factors MADS-box genes are involved in many aspects of plant development, including essential roles in reproduction such as specification of floral organ identity, and regulatory roles during seed and fruit development [47]. Strikingly, a set of co-regulated and interacting MADS-box transcription factors [48] are associated with large seeds. The Arabidopsis interactome [49] visualized through the interaction viewer http:// bbc.botany.utoronto.ca/interactions/ shows the interactions between these MADS box proteins (Figure 4). Similar shared functions of the AGAMOUS-LIKE gene clusters have been demonstrated in early endosperm development and have been implicated in interspecific incompatibility [50,51]. These notably include PHE1 (At1g65330) and its close homologue PHE2 (At1g65300), which are both overexpressed in $2 \times X 4 x, 2 \times X 6 x$, and fis1X2x. PHE1 was previously identified as overexpressed in fis $1 /$ mea mutants in a microarray experiment performed on younger seeds than we used here [28]. PHE1 and PHE2 share the same Affymetrix probeset and therefore either transcript may have been responsible for the signal. The Agilent array contains separate probes for these two genes but due to sequence similarity, cross- hybridization was still a possibility. However qRT-PCR using gene-specific primers gave similar expression profiles for both genes (Additional file 4 table S4), indicating that both PHE1 and PHE2 are likely to be upregulated in seeds with paternal excess or a paternalizing fis $1 \mathrm{X} 2 \mathrm{x}$ mutation. This scenario is supported by the observation that PHE1 expression is repressed by FIS1/MEA, an inhibitor of proliferation [10]. In our microarray data, the MADS-box genes AGL28 (At1g01530) and AGL40 (At4g36950) were called up in one or more of $2 x X 4 x$, $2 \mathrm{xX} 6 \mathrm{x}$, or fis $1 \mathrm{X} 2 \mathrm{x}$, while our qRT-PCR data showed both genes were overexpressed in all three large seed genotypes (Additional file 4 table S4). These MADS-box genes are co-expressed with $P H E 1$, and their products interact with the PHE1 and PHE2 proteins in yeast two-hybrid assays [48]. We also tested AGL62 (At5g60440) as it was likewise reported to interact with the PHE proteins, and called up in $2 \mathrm{xX} 6 \mathrm{x}$ and fis1X2x; qRT-PCR showed this gene is upregulated in $2 \mathrm{xX} 4 \mathrm{x}, 2 \mathrm{xX} 6 \mathrm{x}$, and fis $1 \mathrm{X} 2 \mathrm{x}$ but not up in $4 x X 2 x$ or $6 x X 2 x$. Several seed defects leading to abortion were observed in agl62 seeds. These seeds have a low number of endosperm nuclei and exhibit precocious endosperm cellularization as well as embryo defects ([52]; unpublished data Bouariky and Tiwari). A further MADS-box gene called up in all three large seed samples, AGL45 (At3g05860), encodes a protein reported to interact with AGL40.

It is interesting to observe that the MADS box proteins interact in different complexes in different backgrounds to regulate endosperm development; AGL 62- AGL80 for endosperm development (Kang et al., 2008), AGL80AGL61 for central cell development [50] and AGL62AGL90 endosperm rescue overcoming post zygotic barrier in $A$ thaliana $\times A$ arenosa crosses [51]. Hence the 
Table 4: Genes called up in $2 \times X 4 x$ and $2 x \times 6 x$, not up in $4 \times X 2 x$ and $6 x \times 2 x$.

\begin{tabular}{|c|c|c|c|}
\hline Atld & symbol & annotation & GO biological process (function) \\
\hline At1g03445 & BSU1 & serine/threonine phosphatase & brassinosteroid mediated signalling \\
\hline At1g13680 & & phospholipase C, similar to MAP3K-like protein kinase & intracellular signalling cascade \\
\hline At1g17770 & SUVH7 & SU(VAR)3-9 homolog, a SET domain protein & chromatin modification \\
\hline At1g22090 & EMB2204 & unknown protein & embryonic development \\
\hline At1g44090 & ATGA200X5 & gibberellin 20-oxidase & (isopenicillin-N synthase activity) \\
\hline At1g48010 & & $\begin{array}{l}\text { invertase/pectin methylesterase inhibitor family protein } \\
\text { small, secreted, cysteine rich protein with sequence } \\
\text { similarity to }\end{array}$ & (pectinesterase inhibitor activity) \\
\hline At1g60985 & SCRL6 & SCR (S locus cysteine-rich protein) & signal transduction \\
\hline At1g65300 & PHE2/AGL38 & MADS-box family transcription factor & regulation of transcription \\
\hline \multirow[t]{2}{*}{ At1g65330 } & PHE1/AGL37 & MADS-box family transcription factor & $\begin{array}{l}\text { regulation of transcription/ } \\
\text { embryonic development }\end{array}$ \\
\hline & & bifunctional cytosolic hydroxymethyldihydropterin & \\
\hline At1g69190 & & $\begin{array}{l}\text { pyrophosphokinase/dihydropteroate synthase (HPPK/ } \\
\text { DHPS) }\end{array}$ & response to oxidative stress \\
\hline \multirow[t]{2}{*}{ At1g71770 } & PAB5 & polyadenylate-binding protein & translational initiation \\
\hline & & protease inhibitor/seed storage/lipid transfer protein (LTP) & \\
\hline At1g73560 & & family protein & lipid transport \\
\hline At1g73610 & & GDSL-motif lipase/hydrolase family protein & lipid metabolic process \\
\hline At1g77510 & ATPDIL1-2 & protein disulfide isomerase & cell redox homeostasis \\
\hline At2g02000 & GAD3 & glutamate decarboxylase, calmodulin binding & carboxylic acid metabolic process \\
\hline At2g02010 & GAD4 & glutamate decarboxylase, calmodulin binding & carboxylic acid metabolic process \\
\hline At2g02490 & & unknown protein & unknown \\
\hline At2g02515 & & unknown protein & unknown \\
\hline At2g15740 & & zinc finger ( $\mathrm{C} 2 \mathrm{H} 2$ type) family protein & regulation of transcription \\
\hline At2g18490 & & zinc finger ( $\mathrm{C} 2 \mathrm{H} 2$ type) family protein & regulation of transcription \\
\hline At2g23170 & $\mathrm{GH} 3.3$ & IAA-amido synthase & $\begin{array}{l}\text { response to auxin stimulus/auxin } \\
\text { homeostasis }\end{array}$ \\
\hline At2g25330 & & meprin and TRAF homology domain-containing protein & unknown \\
\hline At2g 25700 & ASK3 & E3 ubiquitin ligase SCF complex subunit SKP1/ASK1 (At3) & (ubiquitin-protein ligase activity) \\
\hline At2g26050 & & zinc ion binding & unknown \\
\hline At2g30810 & & gibberellin-regulated family protein & response to gibberellin stimulus \\
\hline At2g36560 & & DNA-binding protein-related & unknown \\
\hline At2g39640 & & glycosyl hydrolase family 17 protein & carbohydrate metabolic processes \\
\hline At2g43670 & & glycosyl hydrolase family 17 protein & unknown \\
\hline At2g 45110 & ATEXPB4 & beta-expansin & $\begin{array}{l}\text { cellulose and pectin-containing cell } \\
\text { wall loosening }\end{array}$ \\
\hline At3g02670 & & proline-rich family protein & phosphate transport \\
\hline At3g05460 & & sporozoite surface protein-related & unknown \\
\hline At3g05860 & AGL45 & MADS-box family transcription factor & regulation of transcription \\
\hline At3g10780 & & emp24/gp25L/p24 family protein & intracellular protein transport \\
\hline & & & $\begin{array}{l}\text { cell redox homeostasis/intracellular } \\
\text { signalling }\end{array}$ \\
\hline At3g11920 & & glutaredoxin-related & cascade \\
\hline At3g17150 & & pectinesterase inhibitor & (pectinesterase inhibitor activity) \\
\hline
\end{tabular}


Table 4: Genes called up in $2 \times X 4 x$ and $2 \times X 6 x$, not up in $4 \times X 2 x$ and $6 \times X 2 x$. (Continued)

\begin{tabular}{|c|c|c|c|}
\hline At3g21410 & FBW1 & F-box family protein & $\begin{array}{l}\text { ubiquitin-dependent protein } \\
\text { catabolic process }\end{array}$ \\
\hline At3g24510 & GIG2 & defensin-like (DEFL) family protein & unknown \\
\hline At3g49770 & & unknown protein & unknown \\
\hline At3g57160 & & unknown protein & unknown \\
\hline At3g57270 & BG1 & glycosyl hydrolase family 17 protein, beta-1,3-glucanase & carbohydrate metabolic process \\
\hline At4g16500 & & cysteine protease inhibitor family protein & (enzyme regulator activity) \\
\hline \multirow[t]{2}{*}{ At4g25530 } & FWA & homeodomain protein & regulation of transcription \\
\hline & & $\begin{array}{l}\text { small, secreted, cysteine rich protein with sequence } \\
\text { similarity to }\end{array}$ & \\
\hline \multirow[t]{2}{*}{ At4g29285 } & LCR24 & the PCP (pollen coat protein) gene family & unknown \\
\hline & & chromatin remodeling factor, strong similarity to $\mathrm{CHD} 3$ & $\begin{array}{l}\text { chromatin assembly or } \\
\text { disassembly/regulation of }\end{array}$ \\
\hline At4g31900 & & (PICKLE) & transcription \\
\hline At4g32105 & & galactosyltransferase & protein amino acid glycosylation \\
\hline At4g35725 & & unknown protein & unknown \\
\hline At4g36590 & AGL40 & MADS-box transcription factor & regulation of transcription \\
\hline At4g37360 & CYP81D2 & cytochrome P450 family protein & electron transport \\
\hline At4g39650 & GGT2 & gamma-glutamyltranspeptidase & glutathione catabolic process \\
\hline \multirow[t]{2}{*}{ At5g05260 } & CYP79A2 & cytochrome P450 & $\begin{array}{l}\text { glucosinolate biosynthesitic } \\
\text { process }\end{array}$ \\
\hline & & protease inhibitor/seed storage/lipid transfer protein (LTP) & \\
\hline At5g09370 & & family protein & lipid transport \\
\hline At5g09730 & BXL3 & glycosyl hydrolase family 3 protein, beta-xylosidase & carbohydrate metabolic process \\
\hline At5g10440 & CYCD4;2 & cyclin family protein & $\begin{array}{l}\text { regulation of progression through } \\
\text { cell cycle }\end{array}$ \\
\hline At5g12070 & & self-incompatibility protein-related & unknown \\
\hline At5g14960 & E2L1/DEL2 & transcription factor/E2F-like repressor & $\begin{array}{l}\text { regulation of progression through } \\
\text { cell cycle }\end{array}$ \\
\hline At5g20710 & BGAL7 & beta-galactosidase & lactose catabolic process \\
\hline At5g34883 & & unknown protein & unknown \\
\hline At5g34885 & & unknown protein & unknown \\
\hline At5g40040 & RPP2E & $60 S$ acidic ribosomal protein $\mathrm{P} 2$ & translational elongation \\
\hline At5g46950 & & invertase/pectin methylesterase inhibitor family protein & (pectinesterase inhibitor activity) \\
\hline At5g50480 & & CCAAT-box binding transcription factor Hap5a & regulation of transcription \\
\hline At5g54220 & & defensin-like (DEFL) family protein & Unknown \\
\hline
\end{tabular}

*bold Atld = also down in $4 \times 2,6 \times 2$ (SLR/pSLR $\leq-0.6)$

$\mathrm{Up}=(\mathrm{SLR} / \mathrm{pSLR} \geq 0.6)$, not up $=(\mathrm{SLR} / \mathrm{pSLR}(\leq 0.3)$.

GO annotations were obtained from TAIR (http://www.arabidopsis.org/tools/bulk/go/index.jsp; Berardini et al., 2004). GO function terms are provided where no biological process terms were annotated. 
overexpressed AGLs in our dataset may very well interact as higher order complexes to regulate endosperm development in the interploidy crosses and/or be part of a transcriptional cascade promoting seed growth.

Overexpression of individual genes e.g., AGL28, PHE1, AGL40 under the endosperm specific promoter of At5g46950 [53] did not result in any significant change in seed size, overexpression of PHE2 under the same promoter however yielded slightly heavier seeds (unpublished data Tiwari et al). This might indicate that two or more members need to be overexpressed for a visible phenotype. Further experiments such as study of mutants of one or more members of the complex are required to investigate whether upregulation of these MADS-box genes is a cause or a consequence of enhanced seed growth.

PHE1 is preferentially expressed in endosperm from the paternal allele only, and therefore its expression trend in our data was as expected. We were surprised however to find an oppositely imprinted gene, FWA (At4g25530), also called up in $2 \mathrm{x} \times 4 \mathrm{x}, 2 \mathrm{x} \times 6 \mathrm{x}$, and fis1 $\mathrm{X} 2 \mathrm{x} . F W A$ is a homeodomain transcription factor that is expressed only in endosperm, and only from the maternal alleles $[4,54]$. Therefore we expected $F W A$ to show a complementary expression trend to PHE1, i.e. up in $4 \times \mathrm{X} 2 \mathrm{x}$ and $6 \mathrm{x} \mathrm{X} 2 \mathrm{x}$, but not up in paternal excess crosses. Our qRT-PCR data for $F W A$ supports our microarray data for large seeds and additionally calls $F W A$ down in $4 \times \mathrm{X} 2 \mathrm{x}, 6 \mathrm{x} \mathrm{X} 2 \mathrm{x}$, and msi1 (Additional file 4 table S4), indicating the microarry data revealed a bona fide expression trend. One possibility to be tested is whether FWA expression might be deregulated in a background of parental imbalance, so that it becomes expressed from paternal alleles, or in the embryo, or both. It was recently reported that PHE1 loses imprinting in interspecific crosses between $A$. thaliana and $A$. arenos $a$ that also generate paternal excess, becoming ectopically expressed from maternal alleles [55]. Another imprinted gene MPC which is paternally imprinted [12], also shows an upregulation in the 2xX6x, and fis $1 \mathrm{X} 2 \mathrm{x}$ crosses but is unchanged compared to the balanced cross $(2 \mathrm{xX} 2 \mathrm{x})$ in the $4 \mathrm{xX} 2 \mathrm{x}$ and $6 \mathrm{xX} 2 \mathrm{x}$. It will be interesting to determine whether both FWA and MPC are deregulated in the case of paternal imbalance.

The transcription factor WRKY10/MINISEED 3 (MINI3) (At1g55600), up in 2xX6x and fis1X2x, also has a known role in seed growth. qRT-PCR confirmed our microarray data and in addition returned an up call for $2 \mathrm{xX} 4 \mathrm{x}$ and a down call for $6 \mathrm{xX} 2 \mathrm{x}$ (Additional file 4 table S4). This expression trend supports a previously reported role for MINI3 in promoting endosperm growth, based on the observation that loss-of-function mini3 mutants produce small seeds with small endosperms that cellularize early [56].

\section{Genes involved in cell proliferation and chromatin} organization Although paternalized seeds display increased and prolonged endosperm proliferation, and delayed or inhibited cytokinesis, few core cell cycle genes were overexpressed in large seeds. The exceptions included two D cyclins, CYCD4;1 (At5g65420) and CYCD4;2 (At5g10440). The former was called up in 2xX6x and fis $1 \mathrm{X} 2 \mathrm{x}$, and the latter was up in all three large seed crosses but not in maternal excess. qRT-PCR confirmed the microarray data for large seeds for both genes, and additionally strengthened the association of CYCD4;2 with seed growth by showing it is downregulated in $4 \times \mathrm{x} 2 \mathrm{x}$ and $6 \times \mathrm{XX} 2 \mathrm{x}$ (Additional file 4 table S4). D cyclins are involved in the $\mathrm{G} 1$ to $\mathrm{S}$ transition and respond to signals such as cytokinin and sucrose [57]. CYCD4;1 was found to be rate-limiting for cell division in germinating seeds [58]. CYCD4;2 has previously been reported to lack the Rb-binding motif and PEST sequence of other D cyclins, but functional assays show it likewise has a role in proliferation [59]. To our knowledge CYCD4;2 is absent or shows extremely low expression in other microarray experiments http://www.genevestigator.ethz.ch and therefore its strong association with seed growth here makes it an interesting candidate for control of cell proliferation in developing seeds. DEL2/E2Fd/ E2L1 (At5g14960), encoding an atpyical E2F, was called up in $2 \times X 4 x$ and $2 \times X 6 x$, and down in maternal excess and msi1; qRT-PCR indicated a similar trend although comparatively lower upregulation in $2 \times 4$ (Additional file 4 table S4). Typical E2F proteins heterodimerize with DP proteins to bind E2F sites in promoters of genes associated with DNA synthesis and replication and cell cycle control, including D cyclins, and may be positive or negative regulators of cell division. In contrast, atypical E2Fs bind E2F sites as monomers and repress E2F-regulated promoters $[60,61]$. The function of DEL2/E2Fd has not yet been described.

Consistent with increased cell proliferation in seeds with paternal excess and inhibited proliferation in maternalized seeds, many genes involved in DNA replication, chromatin organization, RNA translation, or protein synthesis were overexpressed in large seeds and/or down in small seeds. These included histones (Histone H3, At1g09200; Histone H4, At5g59690), genes involved in chromatin modification (SUVH7, At1g17770; FAS1, At1g65470; SDG21/SUVH8, At2g24740), and members of the Origin of Replication complex (ATORC2, At2g37560; ATORC1a, At4g14700). SUVH7 and SDG21/ SUVH8 are related to animal Su(var)3-9 proteins, which affect chromatin packaging through histone methylation [62], while FAS1 is required for heterochromatin formation [63]. Seeds mutant for ATORC2 undergo very few endosperm or embryo divisions before arresting, indicating that this gene is essential for cell proliferation in the 


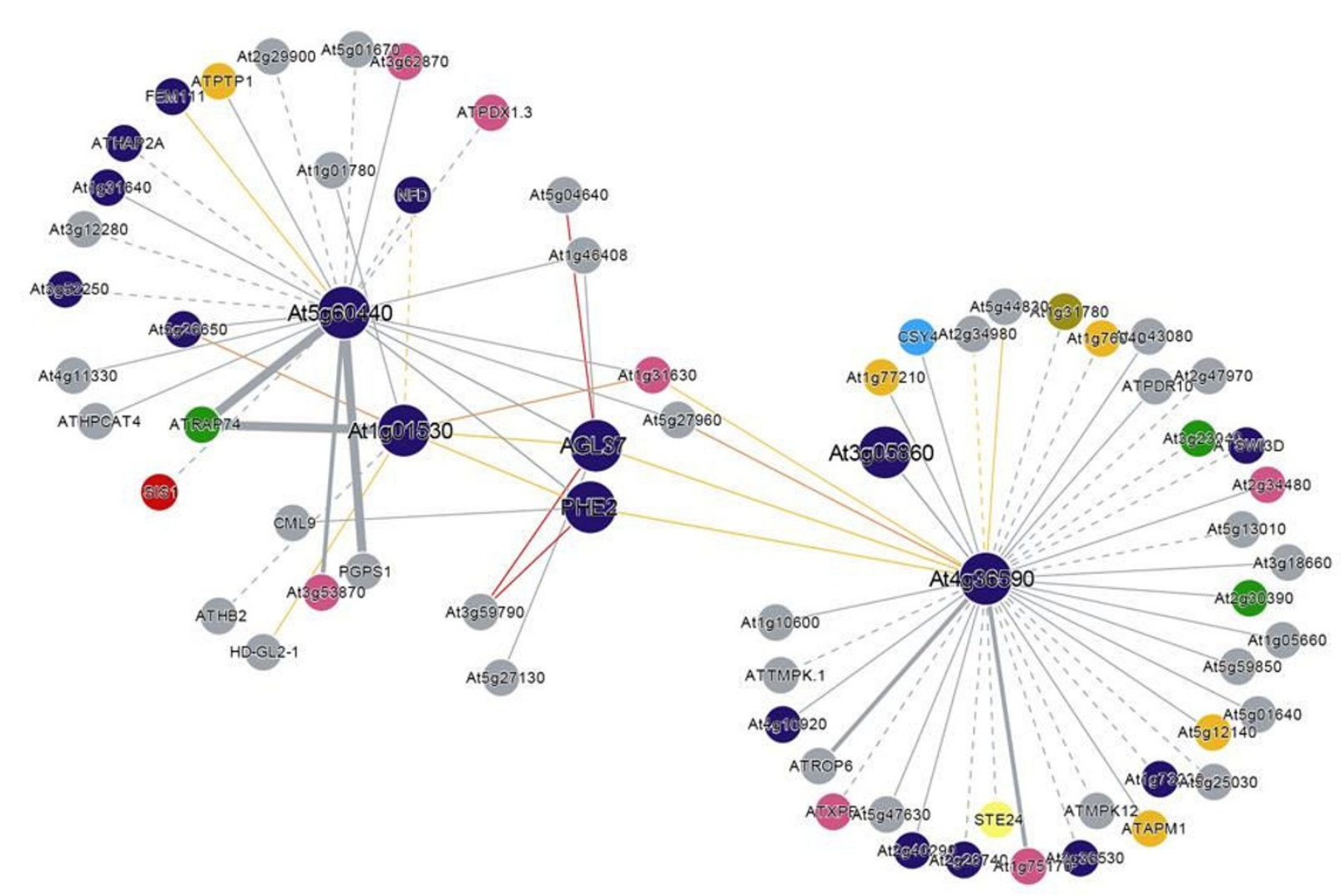

Figure 4 Interaction map for the AGLs overexpressed in 'big seeds'. Big blue circles represent the 5 AGLs overexpressed in the $2 \times 6$ and fis 1 X $2 \times$ crosses.

seed [64]; downregulation of $A T O R C 2$ in $4 \times \mathrm{X} 2 \mathrm{x}$ is consistent with this role. In contrast ATORC1a may be involved in endoreduplication rather than proliferation [65]. Although endoreduplication is not a prominent feature of Arabidopsis endosperm as in maize, there is some evidence for endoreduplication in chalazal endosperm $[66,67]$. ATORC1a was called down in both $4 \mathrm{xX} 2 \mathrm{x}$ and $6 \times \mathrm{X} 2 \mathrm{x}$ seeds, and this could be a factor in the suppression of peripheral endosperm cell division or of chalazal endosperm growth observed in seeds with maternal excess.

Genes involved in hormone pathways We observed differential expression of many genes involved in metabolism or signalling of the hormones cytokinin, gibberellin, brassinosteroid, and auxin. According to our microarray data the cytokinin oxidase CKX2 (At2g19500) is up in $2 \mathrm{xX} 6 \mathrm{x}$ and fis $1 \mathrm{X} 2 \mathrm{x}$; this was confirmed by qRT-PCR (Additional file 4 table S4), which also indicated overexpression in $2 \mathrm{xX} 4 \mathrm{x}$ and $m s i 1$ and underexpression in $4 \mathrm{xX} 2 \mathrm{x}$ crosses. This pattern was at first surprising as cytokinin oxidases catalyse the irreversible degradation of cytokinin, which is associated with cell proliferation. However, recent work shows that $C K X$ overexpression increases seed size in Arabidopsis to a greater extent than can be completely accounted for by the accompanying loss of fertility [68]. Gibberellic acid (GA) is known to be required for seed germination but there is also evidence that it is essential for seed growth [69]. Several genes involved in GA metabolism or response were upregulated in large seeds: these included GA1 (At4g02780), encoding a copalyl diphosphate synthase that catalyses the first committed step in GA biosynthesis, At1g44090, encoding a member of the GA 20-oxidase family that catalyses synthesis of bioactive GA, and At2g30810, a GA-regulated family protein. This last gene had a particularly strong association with seed growth, showing very high levels of overexpression both in microarray data and in qRT-PCR-according to the latter, 18 -fold in $2 \times \mathrm{xX} 4 \mathrm{x}, 69$-fold in $2 \mathrm{xX} 6 \mathrm{x}$, and 30 -fold in fis $1 \mathrm{X} 2 \mathrm{x}$--and severe underexpression in $4 \mathrm{xX} 2 \mathrm{x}, 6 \mathrm{xX} 2 \mathrm{x}$, and msi1. Other microarray experiments show this gene is highly expressed in siliques and also present in isolated seeds http://www.genevestigator.ethz.ch, but no function has been reported. Brassinosteroids (BRs) promote cell growth and division, and are most abundant in pollen and immature seeds [70]. Genes involved in BR synthesis or response that were up in large 
seeds or down in small seeds included BSU1 (At1g03445), encoding a serine threonine phosphatase preferentially expressed in elongating cells which is involved in response to BRs [71]; and DWF4 (At3g50660), whose product catalyses a rate-limiting step in BR synthesis [72]. Further genes involved in hormone metabolism and function are annotated on the lists in Additional file 5 table S5, S5.1-3.

\section{Genes associated with small/underproliferating seeds}

Seeds with maternal excess are characterized by a small seed cavity, inhibited proliferation and early cellularization of endosperm, small chalazal endosperm, and absence of endosperm nodules. One hundred-nineteen genes were overexpressed in $4 \mathrm{xX} 2 \mathrm{x}$ but not in $2 \mathrm{xX} 4 \mathrm{x}$ and $2 \mathrm{xX} 6 \mathrm{x}$, and of these 31 were also up in $6 \mathrm{xX} 2 \mathrm{x}$, and 16 in msil as well (Table 5 and Additional file 5 table S5, S5.4). Unfertilized $m s i 1$ seeds have no chalazal endosperm or nodules, and fewer endosperm nuclei than a fertilized FIS-class mutant would produce, but in contrast to seeds with maternal excess, the seed cavity is not notably small in parthenogenetic msil, endosperm fails to cellularize, and embryo development is very limited. Therefore it is not surprising that there was less overlap between the transcriptional profiles of msil and seeds with maternal excess than there was between fertilized fis 1 and seeds with paternal excess. Twelve genes were called down in $2 \mathrm{xX} 4 \mathrm{x}$ but not $4 \times \mathrm{XX} 2 \mathrm{x}$ and $6 \mathrm{xX} 2 \mathrm{x}$ (Additional file 5 table S5, S5.5), and 14 genes were called down in $2 \times X 6 \mathrm{x}$ and fis1X2x (Additional file 5 table S5, S5.6).

Few of the genes positively associated with small seeds had an obvious link to their phenotype, suggesting that seed growth is more likely to be restricted by downregulation than overexpression of key genes. Several genes involved in auxin function were associated with small seeds, including the auxin response factor $A R F 5 / M P$ (At1g19850), up in $4 \times \mathrm{X} 2 \mathrm{x}, 6 \mathrm{xX} 2 \mathrm{x}$, and msi1, which is involved in embryonic patterning and cell expansion [73], and CYP711A1/MAX1 (At2g26170), also up in maternal excess and msil. MAX genes regulate auxin transport capacity by regulating abundance of PIN auxin efflux carrier proteins [74]; it is interesting in this context that PIN4, which is upregulated in $\max 1$ mutants [74,75], is also downregulated in $4 \times \mathrm{X} 2 \mathrm{x}$ crosses. It was surprising to find CYCD3;3 (At3g50070) downregulated in 2xX6x and fis $1 \mathrm{X} 2 \mathrm{x}$, as this has a similar expression pattern during seed germination to $C Y C D 4 ; 1$ [58], which is up in these crosses (see above); this could reflect different roles for these D cyclins during earlier seed development.

\section{Genes upregulated in FIS-class mutants}

Genes overexpressed in both fis1X2x and msi1 (165 genes, Additional file 5 table S5, S5.7) could include some that are deregulated by FIS-class mutations and involved in the overproliferation of fis mutant endosperms. This is supported by the appearance of PHE1 in this list, which is controlled by the FIS1- and MSI1-containing PRC2; overexpression of this gene in unfertilized msi1 seeds is particularly striking as they contain no paternally contributed alleles, which normally contribute the great majority of PHE1 expression. Similarly, ectopic expression of PHE1 was reported in unfertilized fis3/fie seeds [28]. Further candidate growth-promoting genes overexpressed in fis1X2x and msil are the transcription factors PHE2, AGL45, and AGL62, all discussed above. Other upregulated genes that could be involved in the ectopic seed growth observed in fis mutants include the MADS box genes AGL35 (At5g26630) and AGL73 (At5g38620); ATGA3OX4 (At1g80330), encoding a gibberellin 3-oxidase preferentially expressed in flowers and siliques that catalyses synthesis of bioactive GA [76]; and CPD (At5g05690), involved in brassinosteroid synthesis.

\section{Conclusion}

Reciprocal interploidy crosses in plants often give complementary seed phenotypes, but little is known about the alterations to transcriptional programmes responsible for this. Here we investigated gene expression underlying the differential development of seeds with paternal or maternal excess. One explanation for interploidy cross phenotypes is that they disrupt the balance of active copies of imprinted genes in the seed. Mutations in FIS-class genes also disrupt imprinting, and fertilized seeds of FISclass mutants resemble interploidy seeds with lethal paternal excess, while unfertilized FIS-class mutant seeds develop autonomously with no paternal contribution, and have phenotypic attributes of both paternal and maternal excess. Therefore we also profiled fertilized and unfertilized FIS-class mutants to test their transcriptional profiles against seeds with parental genomic imbalance, and to identify genes deregulated by impairment of PRC2 function. Hierarchical clustering and comparison of genes called differentially expressed placed fis $1 \mathrm{X} 2 \mathrm{x}$ seeds in the same group as seeds with paternal excess, showing that the similar phenotypes are indeed underpinned by similar patterns of gene expression. Figure 5A is a schematic diagram of a composite seed summarizing the main features of maternal and paternal excess, and placing the interploidy and fis $1 \mathrm{X} 2 \mathrm{x}$ crosses on the maternal:paternal spectrum based on their transcriptional profiles as described above. msi1 autonomous seeds cluster with maternal excess but also show many differences, which may be due to the paternalizing effect of the FISclass mutation as well as lack of fertilization, and therefore its position on the spectrum is less certain. To learn more about regulation of seed size, we filtered our data for sets of genes strongly associated with enhanced or inhibited seed growth. Genes overexpressed in large seeds but not in small seeds included many candidates for factors controlling seed growth, such as a group of 
MADS-box transcription factors encoding interacting proteins (Fig. 5B), cell cycle genes, and genes involved in hormone pathways. Some of these genes are also overexpressed in unfertilized FIS-class mutants, suggesting particularly strong association with endosperm proliferation. It would be interesting to study whether any methylation differences that exist between genes in the different interploidy crosses contribute towards the imbalance of imprinted gene expression. Methylation asymmetry has been correlated with the monoallelic expression pattern of imprinted genes in the endosperm and with differences in the expression of genes in the embryo and endosperm in both wildtype as well as dme mutant seeds [77,78]. It would also be of interest to look closely at the maternally derived PolIV dependent si-RNAs [79] and the expression pattern of targets of those si-RNAs or progenitors in the interploidy crosses. The work presented here is therefore a step towards understanding the related phenomena of parental genome balance and imprinting.

\section{Methods}

\section{Plant material and pollinations}

The following stocks were used: C24 diploid (2x) hemizygous for an A9-barnase transgene which confers male sterility [80], C24 tetraploid $(4 \times)$ A9-barnase, Col-1 hexaploid (6x), fis1-3 homozygous mutants (= mea-3/ f644, [18]) in the Ler accession, and msi1-2 homozygous mutants [22] in C24. A9-barnase hemizygotes produce male sterile and fertile segregants, which were used as seed and pollen parents respectively in manual pollinations. $6 \times \mathrm{Col}$ was emasculated two days before pollination to produce the $6 \times \mathrm{X} 2 \mathrm{x}$ cross. Siliques were harvested at $5 \mathrm{DAP}$ and pooled from at least five plants per cross. For $2 \times \mathrm{X} 2 \mathrm{x}$ and interploidy crosses, siliques at $5 \mathrm{DAP}$ had a mean length of $1.57 \mathrm{~cm} \pm$ sem 0.02 with no significant differences among crosses (not shown). fis 1X2x siliques had somewhat reduced length $(1.29 \pm 0.04)$, as Ler seed parents produce short, blunt siliques.

Homozygous msi1 mutants were crossed with $2 \times \mathrm{C} 24$ A9-barnase, and male sterile plants in the F1 were scored for presence of the msil mutant allele on the ability of their pistils to elongate without pollination. msi1 siliques were harvested at 7 DAF (days after flower opening), which microscopic inspection suggested was comparable to the 5 DAP stage of a balanced cross. msi1 rather than fis1 mutants were used to generate autonomous seeds as msi1 has a much higher penetrance of autonomous endosperm development [21].

\section{Confocal laser scanning microscopy}

Samples were prepared as in Braselton et al. [81] and imaged using an Axiovert 100M Zeiss LSM510 laser scanning microscope. Feulgen-stained samples were excited using an argon ion laser at $488 \mathrm{~nm}$ and emissions detected at $\geq 515 \mathrm{~nm}$. Images measuring $1024 \times 1024$ pixels were collected using a C-Apochromat $63 \times / 1.2$ water lens, saved in TIFF format, and processed using Photoshop version 8.0

\section{Microarray protocols Affymetrix platform}

Total RNA was extracted from whole siliques of $2 x X 2 x$ (control cross), 2xX4x, 4xX2x, 2xX6x, and 6xX2x (interploidy crosses), and fis $1 \mathrm{X} 2 \mathrm{x}$ crosses at 5 DAP (two biological replicates of each), and unfertilized msi1 siliques at 7 DAF, using an RNeasy Plant Mini Kit (Qiagen), concentrated using an RNeasy MinElute Cleanup Kit (Qiagen), and hybridized to Affymetrix ATH1 Genome Arrays http://www.affymetrix.com at the NASC (Nottingham Arabidopsis Stock Centre) microarray facility (affymetrix.arabidopsis.info). An ATH1 array contains 22,746 distinct non-control oligonucleotide probe sets representing approximately 24,000 genes. At the probe level, the arrays were analysed using Affymetrix GCOS (MASv5). For a detailed description of the MASv5 algorithm see Affymetrix' Statistical Algorithms Description Document http://www.affymetrix.com/support/technical/whitepapers/sadd whitepaper.pdf. A brief summary can be found in Schulz et al. [36]. Using the pairwise comparative variant of the algorithm, each of the eleven experimental samples (two replicates each of four interploidy crosses and fis $1 \mathrm{X} 2 \mathrm{x}$, and one sample of unfertilized msi1) was compared to both biological replicates of the control sample $(2 \mathrm{xX} 2 \mathrm{x})$. For each probe set, this analysis yielded a signal $\log 2$-ratio (SLR) as a measure of the degree of differential expression between the two samples and a change P-value as a measure of confidence in the expression difference. Each interploidy cross, fis1X2x, and unfertilized $m s i 1$ was compared with both replicates of the control $2 \times \mathrm{X} 2 \mathrm{x}$ cross, resulting in four SLR values for all experiments with biological replicates and two SLR values for $m s i 1$.

\section{$P$-value weighting of Affymetrix SLRs}

Each Affymetrix probe set is synonymous for ten P-values and SLRs, one for each array comparison (interploidy or msi1 versus $2 \mathrm{xX} 2 \mathrm{x}$ ). To simplify the subsequent analyses, P-value and SLR were combined into a single value $\mathrm{pSLR}=\mathrm{SLR} /(1+\mathrm{e}(2 \mathrm{P}-.1) / .01))$, separately for each array comparison. For P-values close to 0 or 1 that correspond to high statistical confidence in the measured differential expression, the pSLR is essentially identical to the SLR. However, with decreasing statistical confidence, pSLR quickly approaches zero, shrinking large SLRs (both negative and positive) with little supporting statistical evidence for differential expression so that their unreliable and hence, deceptively large values do not interfere with the subsequent analyses. This method has been shown to be a more accurate measure of differential expression 
Table 5: Genes called up in $4 \times \times 2 x$ and $6 x \times 2 x$, not up in $2 \times X 4 x$ and $2 x \times 6 x$.

\begin{tabular}{|c|c|c|c|}
\hline Atld & symbol & annotation & GO biological process (function) \\
\hline At1g13080 & CYP71B2 & cytochrome P450 monooxygenase & heat acclimatino \\
\hline \multirow[t]{2}{*}{ At1g15100 } & RHA2A & RING-H2 finger protein & (protein binding) \\
\hline & & & response to auxin stimulus \\
\hline At1g19850 & ARF5/MP/IAA24 & auxin response factor & (transcription factor activity) \\
\hline \multirow[t]{2}{*}{ At1g23205 } & & $\begin{array}{l}\text { invertase/pectin methylesterase inhibitor } \\
\text { family protein }\end{array}$ & (pectinesterase inhibitor activity) \\
\hline & & $\begin{array}{l}\text { DREB subfamily A- } 5 \text { of ERF/AP2 transcription } \\
\text { factor }\end{array}$ & \\
\hline At1g46768 & RAP2.1 & family & regulation of transcription \\
\hline At1g47960 & C/VIF1 & cell wall/vacuolar invertase & (pectinesterase inhibitor activity) \\
\hline At1g56280 & ATDI19 & drought-responsive family protein & response to water deprivation \\
\hline At1g70670 & & caleosin-related family protein & (calcium ion binding) \\
\hline At1g80170 & & polygalacturonase/pectinase & carbohydrate metabolic process \\
\hline \multirow[t]{2}{*}{ At2g03980 } & & GDSL-motif lipase/hydrolase family protein & lipid metabolic process \\
\hline & & & auxin polar transport/carotenoid \\
\hline At2g26170 & CYP711A1/MAX1 & thromboxane-A synthase & biosynthetic process \\
\hline At2g37130 & PER21 & peroxidase & defense response to fungus \\
\hline At2g37710 & RLK & receptor lectin kinase & response to salicylic acid stimulus \\
\hline At2g39400 & & hydrolase & aromatic compound metabolic process \\
\hline At3g11340 & & $\begin{array}{l}\text { UDP-glucoronosyl/UDP-glucosyl transferase } \\
\text { family protein }\end{array}$ & metabolic process \\
\hline At3g14280 & & unknown protein & unknown \\
\hline At3g17790 & ATACP5/PAP17 & acid phosphatase & cellular phosphate ion homeostasis \\
\hline At3g62650 & & binding & transport \\
\hline At4g10955 & & lipase class 3 family protein & lipid metabolic process \\
\hline At4g10960 & UGE5 & UDP-D-glucose 4-epimerase activity & response to stress \\
\hline At4g11410 & & $\begin{array}{l}\text { short-chain dehydrogenase/reductase (SDR) } \\
\text { family protein }\end{array}$ & metabolic process \\
\hline At4g15420 & & PRLI-interacting factor $\mathrm{K}$ & ubiquitin-dependent protein catabolism \\
\hline At4g18550 & & lipase class 3 family protein & lipid metabolic process \\
\hline At4g21590 & ENDO3 & putative endonuclease & DNA catabolism/stamen development \\
\hline At4g32180 & ATPANK2 & pantothenate kinase & coenzyme A biosynthesic process \\
\hline At5g03200 & & $\begin{array}{l}\text { zinc finger (C3HC4-type RING finger) family } \\
\text { protein }\end{array}$ & $\mathrm{N}$-terminal protein myristoylation \\
\hline At5g20580 & & unknown protein & unknown \\
\hline At5g23660 & MTN3 & homolog of the Medicago nodulin MTN3 & unknown \\
\hline At5g43810 & ZLL/PNH & translation initiation factor & (translation initiation factor activity) \\
\hline At5g44380 & & FAD-binding domain-containing protein & response to oxidative stress \\
\hline At5g46780 & & VQ motif-containing protein & Unknown \\
\hline
\end{tabular}

$\mathrm{Up}=(\mathrm{SLR} / \mathrm{pSLR} \geq 0.6)$, not up $=(\mathrm{SLR} / \mathrm{pSLR}(\leq 0.3)$.

$\mathrm{GO}$ function terms are provided where no biological process terms were annotated. 
than SLR or P-value in isolation [36]. The four pSLR values for each interploidy cross and fis1X2x from the fourway comparison were averaged, resulting in a single pSLR for each. The two pSLR values for $m s i 1$ were also averaged.

\section{Agilent platform}

mRNA was extracted from whole siliques of $2 \times \mathrm{X} 2 \mathrm{x}$ and interploidy crosses as above, and fis $1 \mathrm{X} 2 \mathrm{x}$ crosses, using a hot borate method for total RNA extraction [82] and an Oligotex mRNA Midi Kit (Qiagen) to isolate mRNA, and prepared for hybridization to custom Agilent 22K twodye (Cy3 and Cy5) arrays http://www.chem.agilent.com, each carrying 27,402 non-control 60-mer oligonucleotide probes designed by Ceres, Inc. http://www.ceresinc.com. For each experimental cross (interploidy or fis1X2x), one array was hybridized using a Cy3-labeled sample together with a Cy5-labeled 2xX2x control cross sample using Agilent standard operating protocols. The dyes were then swapped and the experiment repeated on a second array. Each array produced two expression measurements per probe: $s_{\mathrm{ij}}$ for the control sample and $\mathrm{s}_{\mathrm{ij}}^{\prime}$ for the experimental sample where $i$ and $j$ identify array and probe, respectively. All subsequent analyses were based on the $\log 2$-ratios, $\log 2\left(\mathrm{~s}_{\mathrm{ij}}^{\prime} / \mathrm{s}_{\mathrm{ij}}\right)$, of these values. The ratios from the dye swap experiments were averaged to give a single SLR per probe per cross.

\section{Correspondence between Affymetrix probe sets and Ceres probes}

The 28,952 cDNA sequences in the ATH1 database (release 5) were searched for exact matches to the 25-mer perfect match (PM) probes on the ATH1 array $(277,042$ exact PM probe matches). Each Affymetrix probe set contains 11 PM probes. An Affymetrix probe set was considered to match an ATH1 cDNA if 9 out of its 11 PM probes generated exact matches to the cDNA $(22,415$ probe set matches). The Ceres 60 -mer probes were aligned to the ATH1 cDNAs using BLAT (fastMap option) [83]. Only alignments for which $\mathrm{Q}=$ number of matches $/ 60=5 / 6$ were considered a match, leading to a total of 26,440 matches. Per distinct transcript ('AtId') in the ATH1 database, only the best sense match to the latest version of the transcript was retained, leaving 22,961 matches. In addition, the Ceres probes were directly aligned to the target sequences of the Affymetrix probe sets using BLAT as above, producing an additional 6,983 matches. An Affymetrix probe set and a Ceres probe were then considered to correspond to each other if they matched the same transcript or each other. 20,442 distinct pairs composed of an Affymetrix probe set and a Ceres probe fulfilled this condition.

\section{Expression and differential expression pre-filtering}

An Affymetrix probe set and its corresponding Ceres probe had to meet the following preconditions on measured absolute and differential expression in order to be included in the subsequent analysis stages. The sum of a Ceres probe's $\mathrm{Cy} 3$ and $\mathrm{Cy} 5$ signals had to exceed 50 in both dye-swap experiments for at least one cross, which excludes unreliable measurements due to low expression. A similar precondition was applied to Affymetrix probe sets. Specifically, probe sets that were called absent by GCOS (detection P-value > 0.06) on both the balanced cross and all the interploidy and msil arrays were excluded. These preconditions were met by 15,134 Affymetrix probe sets and their corresponding Ceres probes, which corresponded to 14,944 unique AtIds.

\section{Expression change threshold}

Data filtering was performed using Microsoft Access. A gene was called up- or down-regulated compared to the balanced $2 \times X 2 x$ cross if it's SLR (Agilent) or pSLR (Affymetrix) was $\geq 0.6$ or $\leq-0.6$ respectively. This corresponds to a change in expression of approximately $50 \%$. After initial analysis, we only called a gene up or down if these criteria were fulfilled in both platforms. A gene called 'not up' had an SLR and pSLR of $\leq 0.3$ (expression change of approximately $20 \%$ ), and a gene called not down' had an SLR and pSLR of $\geq-0.3$.

\section{Hierarchical clustering of samples}

Expression data from both Agilent and Affymetrix experiments were loaded into TIGR Mev [84]. A 50\% variance filter was applied to the dataset and hierarchical clustering was performed using the Pearson Correlation distance metric and the complete linkage method. To check the robustness of the clusters, clustering of samples was repeated with the Covariance and Cosine correlation distance metrics. Principal Component Analysis of the samples [85] was also done in Mev using the default covariance metric and number of neighbours for KNN imputation value of 10 .

\section{qRT-PCR}

Crosses were performed and siliques harvested as for microarray experiments (above). Total RNA was extracted from whole siliques using an RNeasy Mini Kit (Qiagen) and subjected to an on-column DNase treatment and a further in-solution DNase treatment. Extracted RNA was further purified and concentrated using an RNeasy MinElute Cleanup Kit (Qiagen) following manufacturer's instructions. Total RNA was quantified using a spectrophotometer (WPA Lightwave) and integrity checked by gel electrophoresis. Primers were designed and checked for secondary structures, hairpins and dimers using NetPrimer (Premier Biosoft International). A standard RT-PCR was done using the primers, and amplification of a single product and absence of primer dimers was verified by standard gel electrophoresis. 


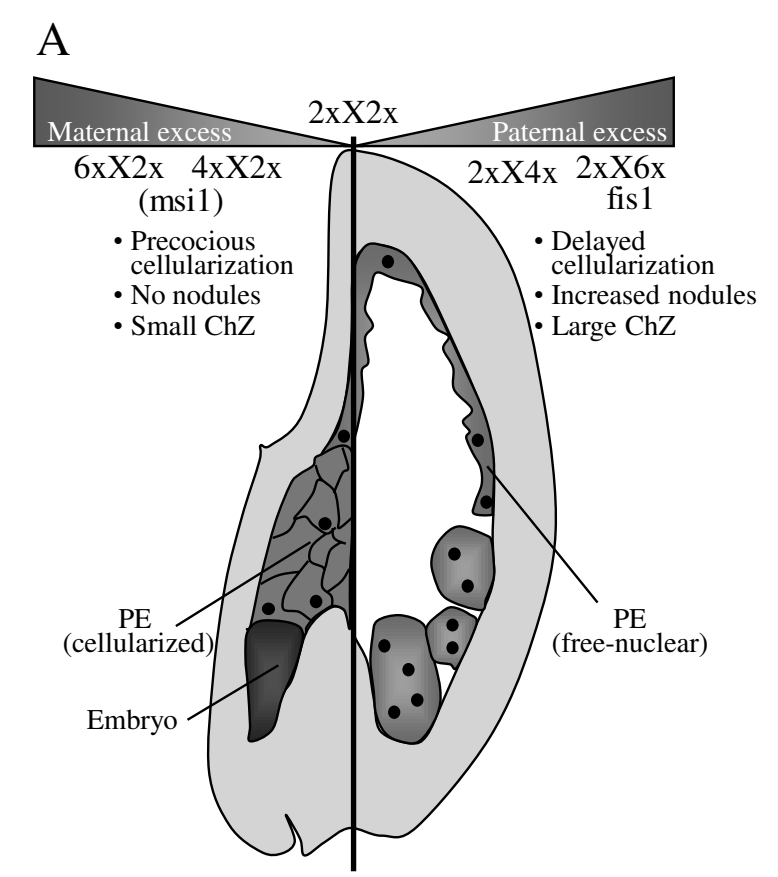

B

\begin{tabular}{|c|c|c|}
\hline \multirow[t]{2}{*}{ 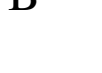 } & \multicolumn{2}{|c|}{ Expression } \\
\hline & Maternal excess & Paternal excess \\
\hline PHE1) & & \\
\hline PHE2 & & \\
\hline AGL28 & DOWN/ & UP \\
\hline AGL40 & NOT UP & \\
\hline AGL45 & & \\
\hline AGL62 & & \\
\hline
\end{tabular}

Figure 5 Relationship between phenotype and gene expression resulting from interploidy crosses and the fis 1 mutation. (A) Composite seed showing the major phenotypic characteristics of maternal and paternal excess crosses. Cellularization/differentiation of endosperm proceeds from the micropylar ('maternal') to chalazal ('paternal') pole, occurring precociously in maternal excess and late or never in paternal excess. Chz = chalazal endosperm, $\mathrm{PE}=$ peripheral endosperm. Transcriptional profiling shows that fis $1 \times 2 \times$ seeds are strongly similar to extreme paternal excess in gene expression as well as phenotype. (B) PHE1 and other MADS-box transcription factors that encode interacting proteins are upregulated in paternal excess/fis 1 and down or unchanged in maternal excess. Therefore these are strong candidates for key regulators of the interploidy cross phenotypes.

qRT-PCR was performed using a Superscript III Platinum Two Step qRT-PCR Kit (Invitrogen). Briefly $1 \mu \mathrm{g}$ of total RNA was used along with oligo dt and random primers and first strand cDNA synthesis was done at $46^{\circ} \mathrm{C}$ for $90 \mathrm{~min}$. The synthesized cDNA was treated with RNaseH. Different dilutions of the cDNA (1:10, 1:20, 1:30, and 1:50) were prepared and $2 \mu$ of each dilution were used in a PCR reaction. Primers and annealing temperatures are shown in Additional file 6 table 6 online.
Four genes were tested for suitability as controls for constant expression across all the samples. These were At1g13440 (GAPDH), At3g04120 (GAPC), At3g18780 (Actin2), and At5g44200 (CBP20). Of these GAPC was found to have the most consistent expression and was used as a control for normalizing differential transcription efficiency and RNA amounts. Real-time PCR was done on a DNA Engine Opticon 2 (Bio-Rad). Typical cycling conditions were $95^{\circ} \mathrm{C}$ for 8 min followed by 45 cycles of $95^{\circ} \mathrm{C}$ for $15 \mathrm{sec}$, annealing temp X (see Additional file 6 table 6) for $15 \mathrm{sec}, 72^{\circ} \mathrm{C}$ for $20 \mathrm{sec}$; plate read after each cycle; melting curve $38-98^{\circ} \mathrm{C}$ read every $0.5^{\circ} \mathrm{C}$ hold for 6 sec. Opticon 2 software calculates the reaction efficiencies without the need of a standard curve (Opticon 2 manual). The efficiencies were used to calculate the relative expression levels of the candidate genes in the experimental samples (siliques from interploidy crosses, fis1 $\mathrm{x} 2 \mathrm{x}$ or unpollinated msi1) compared to the control sample $(2 \times \mathrm{X} 2 \mathrm{x})$ at 5 DAP using the pffafl equation [86] where Ratio $=(\text { Efficiency Target })^{\Delta C T}$ target $(2 \times X 2 x$-experimental sample)/(Efficiency Ref) $\Delta \mathrm{CT}$ ref (2xX2x-experimental sample). Amplification of a single product was verified by a melting curve at the end of the reaction. Two to nine reactions were run per sample, depending on the variability observed, and averaged to obtain a mean expression level.

\section{Accession numbers}

Agilent and Affymetrix microarray data have been desposited in the GEO public repository http:// www.ncbi.nlm.nih.gov/projects/geo/ under the accession numbers GSE20007.

\section{Additional material}

Additional file 1 Masterlist containing unique Atids used for further analysis. Table S1. List of Genes called present in at least one seed sample along with corresponding probesets, and averaged SLRs and pSLRs for each platform ( $\mathrm{Ag}=$ Agilent; Af = Affymetrix). Table S1.1. List of Early seed specific genes (Day et.al. 2008) present in the dataset.

Additional file $\mathbf{2}$ Upregulated and downregulated genes in individual platforms. Table S2. List of Genes called up (Affymetrix PSLR or Agilent SLR $\geq 0.6$ ) or down ( $\leq-0.6)$ in each sample in the individual platforms.

Additional file 3 Upregulated and downregulated genes common in both platforms. S3. List of genes that are upregulated or downregulated in both the platforms.

Additional file 4 qRT-PCR results. S4. qRT-PCR data files and assembled graphs depicting changes to gene expression of selected genes and their agreement with both the Agilent and Affymetrix microarray data.

Additional file 5 Genes associated with paternal excess, maternal excess, or FIS-class mutations. S5. Analysis of all the interploidy crosses and the fis mutants to find genes associated with paternal excess, maternal excess, or FIS-class mutations. Table S5.1. 2xX4x up (4xX2x, 6xX2x not up). Genes also up in $2 x \times 6 x$ and fis $1 \times 2 x$ are marked. Table S5.2. $2 x X 6 x$, fis $1 X 2 x$ up ( $4 x X 2 x, 6 x X 2 x$ not up). Genes also up in $2 x X 4 x$ are marked. Table S5.3 $4 \times X 2 x$ down $(2 x X 4 x, 2 x \times 6 x$ not down). Genes also down in $6 x X 2 x$ and msi1 are marked. Table S5.4 4xX2x up ( $2 x \times 4 x, 2 \times X 6 x$ not up). Genes also up in $6 \times X 2 x$ and msi1 are marked. Table S5.5 2xX4X down (4XX2x, 6xX2x not down). Table S5.6 2xX6x, fis $1 \times 2 x$ down ( $4 x \times 2 x, 6 \times X 2 \times$ not down) Table S5.7 fis $1 \times 2 x$, msi1 up. 
Additional file 6 Additional information about the qRT-PCR S6. Primers and annealing temperatures for qRT-PCR.

\section{Authors' contributions}

ST carried out all the RNA extractions, prepared samples for Affymetrix microarray work, and all of the GRT PCR work. She also performed the downstream data analysis as well as helped prepare the manuscript. RS has processed the raw microarray data and done the normalisations and the statistical calculations. MS and RJS have prepared the manuscript as well as helped design the experimental programme and gave intellectual guidance. RP and group (AS, KZ) have performed the Agilent microarray experiment and provided the raw data. RO and GK have given intellectual inputs to the programme. All authors have read and approved the final manuscript.

\section{Acknowledgements}

We thank Rinke Vinkenoog for preparation of materials for the Agilent microarray work, Marga Frontera for advice on QRT-PCR, Robert Fischer for fis 1-3 mutants, Fred Berger for msi1-2 mutants, Eric van der Graff for $4 \times$ C24, and the Ohio Arabidopsis Stock Centre for $6 \times$ Col. This work was supported by BBSRC (grant no. BBSB05532) and Ceres, Inc.

The author responsible for distribution of materials integral to the findings presented in this article in accordance with the policy described in the Instructions for Authors http://www.biomedcentral.com/bmcplantbiol/ifora/is: Rod J. Scott

bssrjs@bath.ac.uk

\section{Author Details}

'Department of Biology and Biochemistry, University of Bath, Claverton Down, Bath BA2 7AY, UK, 2Department of Medical and Molecular Genetics, King's College London School of Medicine at Guy's, King's College and St Thomas' Hospitals, 8th Floor Guy's Tower, London SE1 9RT, UK, 3Laboratory of Developmental Genetics and Imprinting, The Babraham Institute, Babraham Research Campus, Cambridge CB2 4AT, UK and ${ }^{4}$ Ceres Inc., 1535 Rancho Conejo Boulevard, Thousand Oaks, CA 91320, USA

Received: 9 October 2009 Accepted: 20 April 2010

Published: 20 April 2010

\section{References}

1. Haig D, Westoby M: Genomic imprinting in endosperm: its effect on seed development in crosses between species, and between different ploidies of the same species, and its implications for the evolution of apomixis. Phil Trans R Soc Lond B 1991, 333:1-13.

2. Gehring $M$, Choi Y, Fischer RL: Imprinting and seed development. Plant Cell 2004, 16:S203-S213.

3. Kinoshita T, Yadegari R, Harada JJ, Goldberg RB, Fischer RL: Imprinting of the MEDEA Polycomb gene in the Arabidopsis endosperm. Plant Cell 1999, 11:1945-1952.

4. Kinoshita T, Miura A, Choi Y, Kinoshita Y, Cao X, Jacobsen SE, Fischer RL, Kakutani T: One-way control of FWA imprinting in Arabidopsis endosperm by DNA methylation. Science 2004, 303:521-523.

5. Vielle-Calzada J-P, Thomas J, Spillane C, Coluccio A, Hoeppner MA Grossniklaus U: Maintenance of genomic imprinting at the Arabidopsis MEDEA locus requires zygotic DDM1 activity. Genes and Development 1999, 13:2971-2982

6. Guo M, Rupe MA, Danilevskaya ON, Yang X, Hu Z: Genome-wide mRNA profiling reveals heterochronic allelic variation and a new imprinted gene in hybrid maize endosperm. Plant Journal 2003, 36:30-44.

7. Gutiérrez-Marcos JF, Pennington PD, Costa LM, Dickinson HG: Imprinting in the endosperm: a possible role in preventing wide hybridization. Philosophical Transactions of the Royal Society of London B 2003 358:1105-1111.

8. Gutiérrez-Marcos JF, Costa LM, Biderre-Petit C, Khbaya B, O'Sullivan DM, Wormald M, Perez P, Dickinson HG: maternally expressed gene1 is a novel maize endosperm transfer cell-specific gene with a maternal parentof-origin pattern of expression. Plant Cell 2004, 16:1288-1301.

9. Gutiérrez-Marcos JF, Costa LM, Dal Prà M, Scholten S, Kranz E, Perez P, Dickinson HG: Epigenetic asymmetry of imprinted genes in plant gametes. Nature Genetics 2006, 38:876-878.
10. Köhler C, Page DR, Gagliardini V, Grossniklaus U: The Arabidopsis thaliana MEDEA Polycomb group protein controls expression of PHERES1 by parental imprinting. Nature Genetics 2005, 37:28-30.

11. Jullien PE, Kinoshita T, Ohad N, Berger F: Maintenance of DNA methylation during the Arabidopsis life cycle is essential for parental imprinting. Plant Cell 2006, 18:1360-1372.

12. Tiwari S, Schulz R, Ikeda Y, Dytham L, Bravo J, Mathers L, Spielman M, Guzmán P, Oakey RJ, Kinoshita T, Scott RJ: MATERNALLY EXPRESSED PAB C-TERMINAL, a novel imprinted gene in Arabidopsis, encodes the conserved C-terminal domain of polyadenylate binding proteins. Plant Cell 2008, 20:2387-2398

13. Jahnke S, Scholten S: Epigenetic resetting of a gene imprinted in plant embryos. Current Biology 2009, 19:1677-1681.

14. Scott RJ, Spielman M, Bailey J, Dickinson HG: Parent-of-origin effects on seed development in Arabidopsis thaliana. Development 1998, 125:3329-3341

15. Olsen O-A: Nuclear endosperm development in cereals and Arabidopsis thaliana. Plant Cell 2004, 16:S214-S227.

16. Cooper DC: Caryopsis development following matings between diploid and tetraploid strains of Zea mays. American Journal of Botany 1951, 38:702-708

17. Leblanc O, Pointe C, Hernandez M: Cell cycle progression during endosperm development in Zea mays depends on parental dosage effects. Plant Journal 2002, 32:1057-1066.

18. Kiyosue T, Ohad N, Yadegari R, Hannon M, Dinneny J, Wells D, Katz A Margossian L, Harada JJ, Goldberg RB, Fischer RL: Control of fertilizationindependent endosperm development by the MEDEA polycomb gene in Arabidopsis. Proc Natl Acad Sci USA 1999, 96:4186-4191.

19. Vinkenoog R, Spielman M, Adams S, Fischer RL, Dickinson HG, Scott RJ: Hypomethylation promotes autonomous endosperm development and rescues post-fertilisation lethality in fie -mutants. Plant Cell 2000, 12:2271-2282

20. Sorensen MB, Chaudhury AM, Robert H, Bancharel E, Berger F: Polycomb group genes control pattern formation in plant seed. Current Biology 2001, 11:277-281

21. Köhler C, Hennig L, Bouveret R, Gheyselinck J, Grossniklaus U, Gruissem W: Arabidopsis MSI1 is a component of the MEA/FIE Polycomb group complex and required for seed development. EMBO J 2003, 22:4804-4814

22. Guitton A-E, Page DR, Chambrier P, Lionnet C, Faure JE, Grossniklaus U, Berger F: Identification of new members Fertilisation Independent Seed Polycomb Group pathway involved in the control of seed development in Arabidopsis thaliana. Development 2004, 131:2971-2981.

23. Spielman M, Vinkenoog R, Dickinson HG, Scott RJ: The epigenetic basis of gender in flowering plants and mammals. Trends in Genetics 2001 17:705-711.

24. Chanvivattana Y, Bishopp A, Schubert D, Stock C, Moon YH, Sung ZR, Goodrich J: Interaction of Polycomb-group proteins controlling flowering in Arabidopsis. Development 2004, 131:5263-5276.

25. Guitton A-E, Berger F: Control of reproduction by Polycomb Group complexes in animals and plants. Int J Dev Biol 2005, 49:707-716.

26. Jullien $\mathrm{PE}$, Katz A, Oliva M, Ohad N, Berger F: Polycomb group complexes self-regulate imprinting of the Polycomb group gene MEDEA in Arabidopsis. Current Biology 2006, 16:486-492.

27. Makarevich G, Leroy O, Akinci U, Schubert D, Clarenz O, Goodrich J, Grossniklaus U, Köhler C: Different Polycomb group complexes regulate common target genes in Arabidopsis. EMBO Rep 2006, 7:947-952.

28. Köhler C, Hennig L, Spillane C, Pien S, Gruissem W, Grossniklaus U: The Polycomb-group protein MEDEA regulates seed development by controlling expression of the MADS box gene PHERES1. Genes Dev 2003, 17:1540-1553.

29. Ohad N, Margossian L, Hsu YC, Williams C, Repetti P, Fischer RL: A mutation that allows endosperm development without fertilization. Proc Natl Acad Sci USA 1996, 93:5319-5324.

30. Chaudhury AM, Ming L, Miller C, Craig S, Dennis ES, Peacock W: Fertilization-independent seed development in Arabidopsis thaliana. Proc Natl Acad Sci USA 1997, 94:4223-4228.

31. Guitton A-E, Berger F: Loss of function of MULTICOPY SUPPRESSOR OF IRA 1 produces nonviable parthenogenetic embryos in Arabidopsis. Current Biology 2005, 15:1-6. 
32. Pylatuik JD, Fobert PR: Comparison of transcript profiling on Arabidopsis microarray platform technologies. Plant Molecular Biology 2005, 58:609-624

33. Grossniklaus U, Vielle-Calzada J-P, Hoeppner MA, Gagliano W: Maternal control of embryogenesis by MEDEA, a Polycomb group gene in Arabidopsis. Science 1998, 280:446-450.

34. Swarbreck D, Wilks C, Lamesch P, Berardini TZ, Garcia-Hernandez M, Foerster H, Li D, Meyer T, Muller R, Ploetz L, Radenbaugh A, Singh S, Swing V, Tissier C, Zhang P, Huala E: The Arabidopsis Information Resource (TAIR): gene structure and function annotation. Nucleic Acids Research 2008, 36:D1009-D1014.

35. Day RC, Herridge RP, Ambrose BA, Macknight RC: Transcriptome analysis of proliferating Arabidopsis endosperm reveals biological implications for the control of syncytial division, cytokinin signalling, and gene expression regulation. Plant Physiology 2008, 148:1964-1984.

36. Schulz R, Menheniott TR, Woodfine K, Wood AJ, Choi JD, Oakey RJ: Chromosome-wide identification of novel imprinted genes using microarrays and uniparental disomies. Nucleic Acids Research 2006, 34:Art No. e88.

37. Guo A, He K, Liu D, Bai S, Gu X, Wei L, Luo J: DATF: a database of Arabidopsis transcription factors. Bioinformatics 2005, 21:2568-2569.

38. Skibbe DS, Wang X, Zhao X, Borsuk LA, Nettleton D, Schnable PS: Scanning microarrays at multiple intensities enhances discovery of differentially expressed genes. Bioinformatics 2006, 22:1863-1870.

39. Eisen MB, Spellman PT, Brown PO, Botstein D: Cluster analysis and display of genome-wide expression patterns. Proc Natl Acad Sci USA 1998, 95:14863-14868

40. Berardini TZ, Mundodi S, Reiser R, Huala E, Garcia-Hernandez M, Zhang P, Mueller LM, Yoon J, Doyle A, Lander G, Moseyko N, Yoo D, Xu I, Zoeckler B, Montoya M, Miller N, Weems D, Rhee SY: Functional annotation of the Arabidopsis genome using controlled vocabularies. Plant Physiol 2004, 135:1-11.

41. Beissbarth T, Speed TP: GOstat: find statistically overrepresented Gene Ontologies within a group of genes. Bioinformatics 2004, 20:1464-1465.

42. Erilova A, Brownfield L, Exner V, Rosa M, Twell D, Scheid OM, Hennig L, Köhler C: Imprinting of the Polycomb group gene MEDEA serves as a ploidy sensor in Arabidopsis. PLoS Genet 2009, 5(9):e1000663.

43. Menges M, de Jager SM, Gruissem W, Murray JAH: Global analysis of the core cell cycle regulators of Arabidopsis identifies novel genes, reveals multiple and highly specific profiles of expression and provides a coherent model for plant cell cycle control. Plant Journal 2005, 41:546-566.

44. Lauber MH, Waizenegger I, Steinmann T, Schwarz H, Mayer U, Hwang I, Lukowitz W, Jürgens G: The Arabidopsis KNOLLE protein is a cytokinesisspecific syntaxin. J Cell Biol 1997, 139:1485-1493.

45. Strompen G, El Kasmi F, Richter S, Lukowitz W, Assaad FF, Jürgens G, Mayer U: The Arabidopsis HINKEL gene encodes a kinesin-related protein involved in cytokinesis and is expressed in a cell cycledependent manner. Current Biology 2002, 12:153-158

46. Vanstraelen M, Inzé D, Geelen D: Mitosis-specific kinesins in Arabidopsis. Trends in Plant Science 2006, 11:167-175.

47. Becker A, Theissen G: The major clades of MADS-box genes and their role in the development and evolution of flowering plants. Molecular phylogenetics and evolution 2003, 29:464-489.

48. de Folter S, Immink RGH, Kieffer M, Paøenicová L, Henz SR, Weigel D, Busscher M, Kooiker M, Colombo L, Kater MM, Davies B, Angenent GC: Comprehensive interaction map of the Arabidopsis MADS box transcription factors. Plant Cell 2005, 17:1424-1433.

49. Lee JG, O'Toole N, Ammar R, Provart NJ, Millar AH, Geisler M: A predicted interactome for Arabidopsis. Plant Physiology 2007, 145:317-329.

50. Steffen JG, Kang I, Portereiko MF, Lloyd A, Drews GN: AGL61 interacts with AGL80 and is required for central cell development in Arabidopsis. Plant Physiology 2008, 148:59-268.

51. Walia H, Josefsson C, Dilkes B, Kirkbride R, Harada J, Comai L: Dosagedependent deregulation of an AGAMOUS-LIKE gene cluster contributes to interspecific incompatibility. Current Biology 2009, 19(13):1128-1132

52. Kang IH, Steffen JG, Portereiko MF, Lloyd A, Drews GN: The AGL62 MADS domain protein regulates cellularization during endosperm development in Arabidopsis. The Plant Cell 2008, 20:635-647.
53. Tiwari S, Spielman M, Day RC, Scott RJ: Proliferative phase endosperm promoters from Arabidopsis thaliana. Plant Biotechnology Journal 2006, 4:393-407.

54. Soppe WJ, Jacobsen SE, Alonso-Blanco C, Jackson JP, Kakutani T, Koornneef M, Peeters AJ: The late flowering phenotype of fwa mutants is caused by gain-of-function epigenetic alleles of a homeodomain gene. Mol Cell 2000, 6:791-802.

55. Josefsson C, Dilkes B, Comai L: Parent-dependent loss of gene silencing during interspecies hybridization. Current Biology 2006, 16:1322-1328.

56. Luo M, Dennis ES, Berger F, Peacock WJ, Chaudhury A: MINISEED3 (MINI3), a WRKY family gene, and HAIKU2 (IKU2), a leucine-rich repeat (LRR) KINASE gene, are regulators of seed size in Arabidopsis. Proc Natl Acad SCi USA 2005, 102:17531-17536.

57. Oakenfull EA, Riou-Khamlichi C, Murray JAH: Plant D-type cyclins and the control of G1 progression. Phil Trans R Soc Lond 2002, 357:749-760.

58. Masubelele NH, Dewitte W, Menges M, Maughan S, Collins C, Huntley R, Nieuwland J, Scofield S, Murray JAH: D-type cyclins activate division in the root apex to promote seed germination in Arabidopsis. Proc Natl Acad Sci USA 2005, 102:15694-15699.

59. Kono A, Ohno R, Umeda-Hara C, Uchimiya H, Umeda M: A distinct type of cyclin D, CYCD4;2, involved in the activation of cell division in Arabidopsis. Plant Cell Rep 2006, 25:540-545.

60. Kosugi S, Ohashi Y: E2Ls, E2F-like repressors of Arabidopsis that bind to E2F sites in a monomeric form. J Biol Chem 2002, 277:16553-16558.

61. Mariconti L, Pellegrini B, Cantoni R, Stevens R, Bergounioux C, Cella R, Albani D: The E2F family of transcription factors from Arabidopsis thaliana. J Biol Chem 2002, 277:9911-9919.

62. Baumbusch LO, Thorstensen T, Krauss V, Fischer A, Naumann K, Assalkhou R, Schulz I, Reuter G, Aalen RB: The Arabidopsis thaliana genome contains at least 29 active genes encoding SET domain proteins that can be assigned to four evolutionarily conserved classes. Nucleic Acids Research 2001, 29:4319-4333.

63. Schönrock N, Exner V, Probst A, Gruissem W, Hennig L: Functional genomic analaysis of CAF-1 mutants in Arabidopsis thaliana. Journal of Biological Chemistry 2006, 281:9560-9568

64. Collinge MA, Spillane C, Köhler C, Gheyselinck J, Grossniklaus U: Genetic interaction of an origin replication complex subunit and the Polycomb Group gene MEDEA during seed development. Plant Cell 2004, 16:1035-1046

65. Diaz-Trivino S, del Mar Castellano M, de la Paz Sanchez M, Ramirez-Parra E, Desvoyes B, Gutierrez C: The genes encoding Arabidopsis ORC subunits are $\mathrm{E} 2 \mathrm{~F}$ targets and the two $\mathrm{ORC1}$ genes are differently expressed in proliferating and endoreduplicating cells. Nucleic Acids Research 2005, 33:5404-5414

66. Boisnard-Lorig C, Colon-Carmona A, Bauch M, Hodge S, Doerner P, Bancharel E, Dumas C, Haseloff J, Berger F: Dynamic analyses of the expression of the HISTONE::YFP fusion protein in Arabidopsis show that syncytial endosperm is divided in mitotic domains. Plant Cell 2001, 13:495-509.

67. Baroux C, Fransz P, Grossniklaus U: Nuclear fusions contribute to polyploidization of the gigantic nuclei in the chalazal endosperm of Arabidopsis. Planta 2004, 220:38-46.

68. Werner T, Köllmer I, Bartrina I, Holst K, Schmülling T: New insights into the biology of cytokinin degradation. Plant Biology 2006, 8:371-381.

69. Swain SM, Singh DP: Tall tales from sly dwarves: novel functions of gibberellins in plant development. Trends in Plant Science 2005, 10:123-129.

70. Shimada Y, Goda H, Nakamura A, Takatsuto S, Fujioka S, Yoshida S: Organspecific expression of brassinosteroid-biosynthetic genes and distribution of endogenous brassinosteroids in Arabidopsis. Plant Physiology 2003, 131:287-297.

71. Mora-García S, Vert G, Yin Y, Caño-Delgado A, Cheong H, Chory J: Nuclear protein phosphatases with Kelch-repeat domains modulate the response to brassinosteroids in Arabidopsis. Genes and Development 2004, 18:448-460

72. Choe S, Dilkes BP, Fujioka S, Takatsuto S, Sakurai A, Feldmann KA: The DWF4 gene of Arabidopsis encodes a cytochrome P450 that mediates multiple 22a-hydroxylation steps in brassinosteroid biosynthesis. Plant Cell 1998, 10:231-244.

73. Hardtke CS, Ckurshumova W, Vidaurre DP, Singh SA, Stamatiou G, Tiwari SB, Hagen G, Guilfoyle TJ, Berleth T: Overlapping and non-redundant 
functions of the Arabidopsis auxin response factors MONOPTEROS and NONPHOTOTROPIC HYPOCOTYL 4. Development 2004, 131:1089-1100.

74. Bennett T, Sieberer T, Willett B, Booker J, Luschnig C, Leyser O: The Arabidopsis MAX pathway controls shoot branching by regulating auxin transport. Current Biology 2006, 16:553-563.

75. Lazar G, Goodman HM: MAX1, a regulator of the flavonoid pathway, controls vegetative axillary bud outgrowth in Arabidopsis. Proc Natl Acad Sci USA 2006, 103:472-476.

76. Mitchum MG, Yamaguchi S, Hanada A, Kuwahara A, Yoshioka Y, Kato T, Tabata S, Kamiya Y, Sun T-P: Distinct and overlapping roles of two gibberellin 3-oxidases in Arabidopsis development. Plant Journal 2006, 45:804-818

77. Gehring M, Bubb KL, Henikoff S: Extensive demethylation of repetitive elements during seed development underlies gene imprinting. Science 2009, 324:1447-1451

78. Hsieh TF, Ibarra CA, Silva P, Zemach A, Eshed-Williams L, Fischer RL, Zilberman D: Genome-wide demethylation of Arabidopsis endosperm. Science 2009, 324:1451-1454.

79. Mosher RA, Melnyk CW, Kelly KA, Dunn RM, Studholme DJ, andBaulcombe DC: Uniparental expression of PollV-dependent siRNAs in developing endosperm of Arabidopsis. Nature 2009, 460:283-286.

80. Paul W, Hodge R, Smartt S, Draper J, Scott R: The isolation and characterisation of the tapetum-specific Arabidopsis thaliana A9 gene. Plant Mol Biol 1992, 19:611-622.

81. Braselton JP, Wilkinson MJ, Clulow SA: Feulgen staining of intact plant tissues for confocal microscopy. Biotech Histochem 1996, 71:55-102.

82. Wilkins TA, Smart LB: Isolation of RNA from plant tissue. In A laboratory guide to RNA: isolation, analysis and synthesis Edited by: Krieg P. New York: Wiley-Liss; 1996:21-41.

83. Kent JW: BLAT - the BLAST-like alignment tool. Genome Research 2002, 12:656-664

84. Saeed Al, Sharov V, White J, Li J, Liang W, Bhagabati N, Braisted J, Klapa M, Currier T, Thiagarajan M, Sturn A, Snuffin M, Rezantsev A, Popov D, Ryltsov A, Kostukovich E, Borisovsky I, Liu Z, Vinsavich A, Trush V, Quackenbush J: TM4: a free, open-source system for microarray data management and analysis. Biotechniques 2003, 34:374-378.

85. Raychaudhuri S, Stuart JM, Altman RB: Principal components analysis to summarize microarray experiments: application to sporulation time series. Pacific Symposium on Biocomputing 2000, 2000:452-463.

86. Pfaffl MW: A new mathematical model for relative quantification in realtime RT-PCR. Nucleic Acids Research 2001, 29:2002-2007.

doi: 10.1186/1471-2229-10-72

Cite this article as: Tiwari et al., Transcriptional profiles underlying parent-oforigin effects in seeds of Arabidopsis thaliana BMC Plant Biology 2010, 10:72

Submit your next manuscript to BioMed Centra and take full advantage of:

- Convenient online submission

- Thorough peer review

- No space constraints or color figure charges

- Immediate publication on acceptance

- Inclusion in PubMed, CAS, Scopus and Google Scholar

- Research which is freely available for redistribution

Submit your manuscript at www.biomedcentral.com/submit
C Biomed Central 